\title{
First evidence for the Homerian (late Wenlock, Silurian) positive carbon isotope excursion from peri-Gondwana: new data from the Barrandian (Perunica)
}

\author{
JIŘ́ FRÝDA \& BARBORA FRÝDOVÁ
}

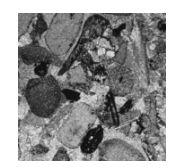

\begin{abstract}
The Homerian (late Wenlock, Silurian) carbon isotope excursion is documented for the first time from peri-Gondwana based on new data from the Barrandian (Perunica). It is also the first time that this excursion has been found outside of the palaeoplates that subsequently formed the supercontinent Laurussia (i.e., Laurentia, Baltica and Avalonia). The typical two-peaked Homerian $\delta^{13} \mathrm{C}$ excursion is documented from a highly fossiliferous shallow-water limestone succession formally established here as the Kozel Limestone Member of the Motol Formation. Application of $\delta^{13} \mathrm{C}$ chemostratigraphy considerably improves the stratigraphic resolution within the Kozel Limestone Member and enables more precise dating of its very diverse fauna. The present data reveal recovery of benthic communities after a series of mid-Homerian extinction events (i.e., the Mulde conodont and the end lundgreni graptolite bioevents) started much earlier than has been hitherto described from other world occurrences. $\bullet$ Key words: Silurian, Homerian carbon isotope excursion, Peri-Gondwana, Perunica, Barrandian area, Kozel Limestone Member.
\end{abstract}

FRÝDA, J. \& FRÝDOVÁ, B. 2014. First evidence for the Homerian (late Wenlock, Silurian) positive carbon isotope excursion from peri-Gondwana: new data from the Barrandian (Perunica). Bulletin of Geosciences 89(3), 617-634 (5 figures, appendix). Czech Geological Survey, Prague. ISSN 1214-1119. Manuscript received November 29, 2013; accepted in revised form February 19, 2014; published online March 20, 2014; issued June 9, 2014.

Jiří Frýda, Faculty of Environmental Sciences, Czech University of Life Sciences Prague, Kamýcká 129, 16521 Praha 6 - Suchdol, and Czech Geological Survey, P.O.B. 85, 11821 Prague 1, Czech Republic; bellerophon@seznam.cz. - Barbora Frýdová, Faculty of Environmental Sciences, Czech University of Life Sciences Prague, Kamýcká 129, 16521 Praha 6-Suchdol

The Silurian Period is the time interval with probably the highest stratigraphic resolution of all of the Palaeozoic periods. The rather cosmopolitan nature of Silurian marine faunas makes possible application of a global chronostratigraphy. The current Silurian timescale assumes a correlation between stage boundaries and graptolite zones (e.g., Loydell 2012) and as a result graptolite-bearing successions can be correlated directly to the global chronostratigraphic zonation (see discussion in Cramer et al. 2010, 2011). However, usage of the global chronostratigraphic zonation in non-graptolitic Silurian successions is more difficult. Silurian conodont as well as organic microfossil biozonations are still generally less precise than graptolite biozonations (e.g., Cramer et al. 2011). For this reason intensive studies of the applicability of different sedimentological, geophysical and geochemical methods for improving the stratigraphic resolution of non-graptolitic Silurian successions were started about 25 years ago. The latter studies have suggested that carbon isotope chemostratigraphy is one of the most promising methods.

The Silurian Period was a time of several distinct and rapid changes in the global carbon cycle. These geochemical events were closely linked to major crises in the marine ecosystem as well as to palaeoclimatic changes (see Jeppsson 1998; Munnecke et al. 2003; Noble et al. 2005, 2012; Loydell 2007; and Calner 2008 for reviews). Some of those perturbations in the carbon cycle have been documented globally (see Calner 2008 for review) and as such they have become important stratigraphic tools for global correlation of Silurian successions. Integration of graptolite, organic microfossil and conodont biostratigraphy with carbon isotope chemostratigraphy seems to be the most promising tools for improvement of Silurian stratigraphic correlation (e.g. Loydell et al. 1998, 2003; Kaljo et al. 2003, 2007; Munnecke et al. 2003; Cramer et al. 2006, 2010, 2011, 2012; Kaljo \& Martma 2006; Jeppsson et al. 2007; Lenz et al. 2006; Loydell \& Frýda 2007, 2011; Calner et al. 2012).

Distinct positive $\delta^{13} \mathrm{C}$ excursions appear to occur throughout the Silurian (see summary and references in Cramer et al. 2011). Only three of these $\delta^{13} \mathrm{C}$ excursions have hitherto been recorded from the Barrandian (Perunica): a) that associated with the late Aeronian graptolite sedgwickii Event (Štorch \& 
Frýda 2009, 2012), b) the mid-Ludfordian excursion associated with the conodont Lau and graptolite kozlowskii events (Lehnert et al. 2003, 2007; Manda et al. 2012; Gocke et al. 2013; Frýda \& Manda 2013), and c) the Silurian-Devonian boundary (Klonk) excursion which is associated with several bioevents (Hladíková et al. 1997, Buggisch \& Mann 2004, Manda \& Frýda 2010).

In this short paper we report for the first time a new Silurian $\delta^{13} \mathrm{C}$ excursion from the Barrandian area - the Homerian (late Wenlock, Silurian) carbon isotope excursion which represents its first recognition in peri-Gondwana (Fig. 1), in contrast to the series of mid-Homerian extinction events (i.e, the Mulde conodont and the end lundgreni graptolite bioevents) which were already reported from the latter area (Štorch 1995, Gutiérrez-Marco et al. 1996, Pittau et al. 2006). Special attention is also paid to an improvement of the internal stratigraphy of the Homerian Kozel Limestone Member (new member) and dating of its very diverse fauna in respect to the mid-Homerian extinction events.

\section{Homerian of the Barrandian}

The Homerian (late Wenlock) strata of the Barrandian form upper part of the Motol Formation. The definition and stratigraphic range of the Motol Formation, named originally as "motolské vrstvy" by Perner \& Kodym (1919), has been changed several times (e.g., Bouček 1934, 1953). According to the present definition by Křiž (1975), the Motol Formation comprises the uppermost Telychian (Llandovery) and the entirety of the Wenlock. The lower part of the Motol Formation is sedimentologically more uniform than its upper part. The formation is represented mostly by calcareous clayey shales. In its middle and upper parts volcanic rocks and limestones are significant. Facies distribution was strongly influenced by synsedimentary tectonic movements and volcanic activity in the upper part of the Motol Formation (Bouček 1934, 1953; Horný 1955a-c, 1960; Kř́ž 1991). The thickness of the Motol Formation varies from $80 \mathrm{~m}$ to $300 \mathrm{~m}$ (Kř́iž 1998).

The Homerian was the period of greatest facies differentiation within the Motol Formation. High activity within several volcanic centres (i.e., Svatý Jan Volcanic Centre, Reporyje Volcanic Centre and Nová Ves Volcanic Centre) gave origin to shallow areas generating a complex facies pattern from very shallow intertidal limestones to deeper water shales deposited in an anoxic environment (see for details Bouček 1953; Horný 1955a-c, 1960, 1962; Fiala 1970; Kř́̌̌ 1991, 1992, 1998; Storch 1998). The central area of the Svatý Jan Volcanic Centre was emergent during the latest Wenlock and Ludlow forming a volcanic island. During the latest Wenlock, shallow water environments surrounding the island gave origin to the mostly crinoidal limestones. The latter shallow water limestones are named and formally established here as the Kozel Limestone Member (new member). Complete definition of this new lithostratigraphic unit of the Motol Formation is given in appendix.

\section{Studied sections}

The sections described in the present paper (49 $57^{\prime} 22.082^{\prime \prime} \mathrm{N}, 1^{\circ} 5^{\prime} 50.293^{\prime \prime}$ E, sections No. 759 and 760 of Křiž et al. 1993; for precise geographic positions of the both sections see Kř́ž 1991, fig. 48) are located in the Central Segment of the Prague Basin. The sections are situated on the left (north) bank of the Berounka River, south of the village of Lištice near Beroun. Hejna (2012) reported a comment made by Josef Antonín Každý (1723-1798) in his chronicle testifying that this area was quarried for limestone already in the eighteenth century. Both sections have been intensively studied since the first half of the nineteenth century. Barrande used the name "Rochers de Kozel" or "Kozel” for this area (Kříž 2013, pers. comm.). The stratigraphic position of both sections was analyzed during the last century (e.g., Kodym et al. 1931; Havlíček et al. 1958; Horný 1955a-c, 1962, 1965, 1971; Kř́iž 1991, 1992, 1998; Kř́̌ž et al. 1993; Dufka 1995; and Manda 1996). The most detailed description of the two sections was given by Kř́ž (1992) and Kříž et al. (1993), who discussed their lithologies, faunal communities and biostratigraphy.

Section No. 759 starts with a lens of grey micritic limestone bearing crinoid detritus and weathered volcanic glass, which was deposited on a thick unit of volcanic rocks. Kř́̌ž (1992) noted an occurrence of the Buceqia obolina brachiopod Community from basal layers of the section. In addition to the nominate brachiopod Buceqia obolina (Barr.), he mentioned the presence of five other brachiopods [Cryptatrypa philomella (Barr.), Bleshidium papalas Havl., Aratoechia minerva (Barr.), Hircinisca cf. rhynchonelliformis Havlíček \& Plodowski, Striispirifer aurelius Havl.], four trilobites [Cheirurus obtusatus Hawle \& Corda, Kosovopeltis inopinata Šnajdr, Odontopleura prevosti prevosti (Barr.), Aulacopleura konincki (Barr.)], and five bivalves ["Nucula" simplicitor Barr., Butovicella migrans (Barr.), Isiola lyra Křǐž, Slava cf. pelerina Kříž, and Cardiola aff. agna Kř́̌ž]. Kř́iž (1992) also noted the occurrence of diverse acritarchs and rare spores found by Pavel Dufka. Only two long-ranging chitinozoan species, Ancyrochitina ancyrea (Eisenack) and Conochitina tuba (Eisenack), were found in section No. 759. About $1 \mathrm{~m}$ above the base of the section (bed No. 6 of Kř́rz 1992) a thick bed of greenish-grey tuffitic shales occurs which contains graptolites Pristiograptus dubius (Suess) s.l., and Monograptus flemingii (Salter), the brachiopod Buceqia obolina, the trilobite Cheirurus obtusatus, and the plant Prototaxites sp. Kř́ž (1992) noted the occurrence of the graptolite Monograptus flemingii also in upper part of 


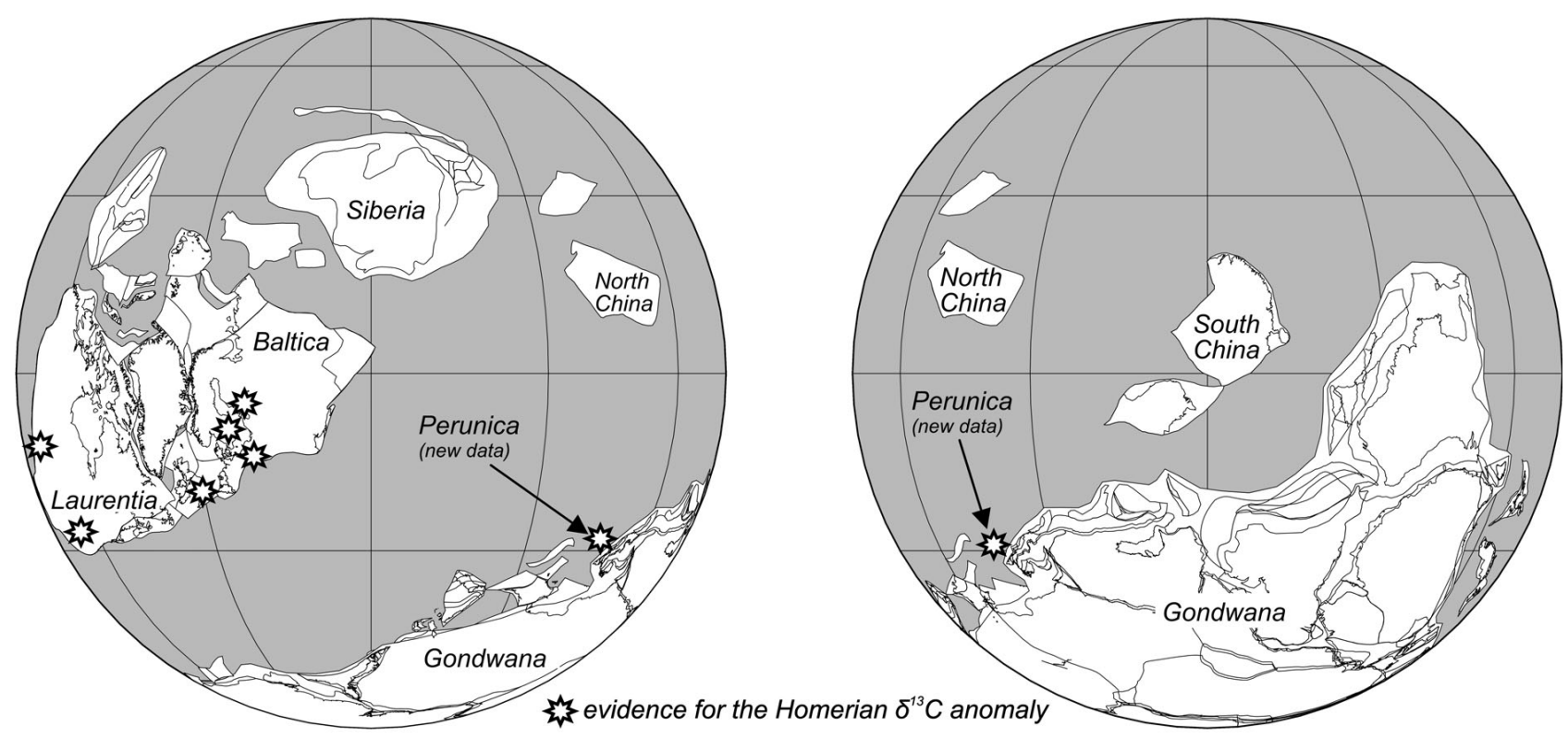

Figure 1. Palaeogeographical distribution of published records of the late Wenlock Homerian $\delta^{13} \mathrm{C}$ excursion based on the review by Calner (2008); palaeogeographical reconstruction modified after Torsvik (2009).

section No. 759, about $7 \mathrm{~m}$ above the base of the limestone sequences. From the same level he also mentioned the occurrence of the conodont species Ozarkodina excavata excavata (Branson \& Mehl) and Kockelella absidata (Barrick \& Klapper). Later Kříž et al. (1993) mentioned the occurrence of Ozarkodina sagitta sagitta (Walliser) from the basal part of section No. 759 (bed No. 3).

Manda (1996) produced a detailed analysis of the fossil community from the lower part of section No. 759 and reported additional species: seven trilobites [Cyphoproetus putzkeri putzkeri Šnajdr, Sphaeroxochus mirus Beyrich, Trochurus speciosus Beyrich, Aulacopleura nitida (Barr.), Leonaspis sp., Harpes crassifrons (Barr.), Bumastus bouchardi (Barr.)], sixteen brachiopods (see below), twenty cephalopods [Parakionoceras mimus (Barr.), Kionoceras bacchus Barr., "Orthoceras" sylphideum Barr., "Orthoceras" littorale Barr., "Orthoceras" valens Barr., Michelinoceras? semilaeve (Barr.), Michelinoceras? cavum (Barr.), Orthocycloceras? pedum (Barr.), Rizosceras cf. latens (Barr.), Rizosceras ignotum (Barr.), Phragmoceras n. sp. aff. gradatum (= Phragmoceras cf. ventricosum Sowerby, see Manda 2007), Plagiostomoceras endymion (Barr.), Plagiostomoceras xanthus (Barr.), Murchisoniceras sp., Pseudocycloceras aff. venustulum Barr., "Orthoceras" aff. memor Barr., Sphooceras truncatum (Barr.), Sphooceras disjunctum (Barr.), Protobactrites styloideum (Barr.), Metarizoceras sp. n.], five bivalves [Nutricula gravida Křǐž, Patrocardia alifera (Barr.), Spanila (= Kenzieana) cardiopsis (Barr.), Slava fibrosa (Sow.), Maminka comata Barr.], one rostroconch (Conocardium sp.), three hyolithids [Hyolithus bicostatus Novák, Hyolithus cultellus Novák, Ceratotheca ungui- formis Novák], two graptolites [Cyrtograptus lundgreni Tullberg, Cyrtograptus cf. perneri Bouček], machaeridian Plumulites minimus Barr., and rugose coral Syringaxon sp.

Manda (1996) established a new Eoplectodonta sowerbyana-Atrypa Community which is, according to him, "known from the southern part of level 3 at locality No. 759 only". The latter community contains two dominant brachiopods, Eoplectodonta sowerbyana (Barr.) (25\%) and Atrypa cf. margarita (Barr.) (10\%), and eighteen less frequent brachiopods [Quasistrophonella haueri (Barr.), Aratoechia minerva, Placocliftonia colibri (Barr.), Oglupes scarabeus Havl., Cyphomena joachimiata Havl., Hircinisca praehircina Havl., Eospirifer praesecans Havl., Striispirifer aurelius, Kozlenia kozlensis Havl., Septatrypa zelia (Barr.), Ptychopleurella sp. n., Leptaena sp., Strophoprion sp., Myriospirifer sp., Isorthis sp., Bleshidium sp., Meristina sp., and Buceqia obolita]. The Eoplectodonta sowerbyanaAtrypa Community contains also five trilobites [Staurocephalus murchisoni (Barr.), Phacopidella glockeri (Barr.), Sphaeroxochus mirus, Kosovopeltis inopinata, and Cheirurus obtusatus], three cephalopods [Protobactrites styloideum, Oonoceras sp., Orthocycloceras pedum], two bivalves [Cardiola agna agna, Butovicella migrans], and one crinoid [Syndetocrinus dartae Kirk].

The second studied section [i.e., section No. 760 of Kř́̌ž (1992) also called "U Drdů" after the family name of the farm owners who lived SE of the section] starts approximately $25 \mathrm{~m}$ stratigraphically above top of the section No. 759. The lower about $20 \mathrm{~m}$ of the section is formed by pyroclastics and granulates, with greenish tuffites containing lapilli and fragments of lava in its upper part. The main 
part of section No. 760, about 63 m thick, consists of limestone beds belonging to the Kozel Limestone Member and representing its stratotype. The section is formed mainly by massive lenticular grey tuffitic bioclastic crinoidal limestone with levels of brown tuffites with small lenses of grey bioclastic crinoidal tuffitic limestones (Figs 2, 3). In the middle part of the section massive limestones occur showing at some levels cross-bedding (e.g., Fig. 4D). Tuffitic layers are almost absent in the uppermost $11 \mathrm{~m}$ of the section. The Kozel Limestone Member of the section No. 760 is overlain by a thick unit of volcanic rocks.

The fauna of the Kozel Limestone Member found at its stratotype section consists mostly of crinoids, corals, bryozoans, stromatoporoids, brachiopods, gastropods and trilobites. The limestone sequence in section No. 760 starts with a sequence of crinoidal limestones interbedded with thin tuffite levels (Figs 3,4). The basal beds of the crinoidal limestones often contain small fragments of tuffites (Fig. 2A) covered by a limonitic layer and they bear a high diversity fauna. Kř́ž (1992) found a rich brachiopod, trilobite, and coral fauna from his beds No. 24 and 25, which contains nineteen brachiopods [Mendacella venustula (Barr.), Resserella canalis (Sow.), Isorthis (A.) cliens Havl., Rhynchotreta cunicula Havl., Anastrophia deflexa (Sow.), Cyrtia spiriferoides Bouček, Rufispirifer nucula (Barr.), Protomegastrophia miranda (Barr.), Striispirifer aurelius, Atrypa margarita, Nucleospira lentilca Havl., Whitfieldella ypsilon (Barr.), Kozlenia kozlensis, Atrypina paulula Havl., Eospirifer praesecans, Amphistrophia harperi Havl., Dicoelosia sp., Strophochonetes gluma (Barr.), Skenidioides sp.], rostroconch Conocardium sp., trilobite Harpidella hama (Šnajdr), and fourteen corals [Heliolites decipiens (McCoy), H. irregularis Wentzel, H. bohemicus Wentzel, $H$. spongodes Lindström, Helioplasmolites wentzeli Galle, Stelliporella lamellata Wentzel, Propora poctai Galle, Favosites fidelis Barr., F. gotlandicus Lamarck, F. forbesi Milne-Edwards \& Haime, Halysites catenularia (Linn.), "Barrandeolites" bowerbanki (Milne-Edwards \& Haime), Entelophyllum confusum (Počta), and E. prosperum (Barr.)]. In addition to those species Kříž (1992) noted also the occurrence of stromatoporoids and bryozoans.

Kříž (1992) found another rich fauna in the middle part of section No. 760 (top of bed No. 60) which includes nine brachiopods [Meristina mora Michalík, Resserella canalis, Atrypa margarita, Strophoprion euglypha (Dalman), Leptostraphiella nebulosa (Barr.), Shagamella margarita (Barr.), Cyrtia spiriferoides, Isortis (Arcuala) cliens, and Protomegastrophia miranda], six trilobites [Proetus kopaninensis Šnajdr, Tropidocoryphe? praecurrens Šnajdr, Interproetus sp., Eophacops trapeziceps Barr., Richterarges sp. n. aff. ambiguus (Barr.), and Cheirurus obtusatus], and stromatoporoids. Kř́žz (1992) reported also nine conodont samples (from beds No. 24, 28, 30, 40 top, 70 bottom,
73 bottom, 82 top, 86 centre and 86 top) from the section No. 760 which gave a uniform fauna characterized only by Ozarkodina bohemica (Walliser).

Havlíček (1995) revised the stratigraphic distribution of brachiopod communities from the Motol and Kopanina formations which was partly based on new material collected by Kř́žz during his study of Wenlock/Ludlow boundary in the Prague Basin (Kříž et al. 1993). Havlíček modified his previous definition of the Hircinisca-Ancillotoechia brachiopod Community (see Havlíček \& Štorch 1990, 1999) which included about 50 brachiopod species. He noted 23 brachiopod species of the Hircinisca-Ancillotoechia brachiopod Community in the basal part (beds No. 24 and 25) of section No. 760, with twelve common species [Mendacella venustula, Resserella canalis, Isorthis (A.) cliens, Linoporella punctata (Vern.), Leptaena sp., Rhynchotreta cunicula, Ancillotoechia ancillans (Barr.), Atrypina paulula, Kozlenia kozlensis, Nucleospira lentilca, Cyrtia spiriferoides and Rufispirifer nucula], eight rare species [Craniops (Paracraniops?) sp., Protomegastrophia miranda, Orhoria amelia Havl., Amphistrophiella cf. funiculata (McCoy), Coolinia pecten (Lin.), Terazkia expandens (Barr.), Krizistrophia miniconcha Havl., and Pliocyrtia sambuca Havl.] and three very rare species [Hostimex hostimensis Havl., Atrypa margarita, and Eospirifer praesecans].

Dufka (1995) published results of his analysis of organic microfossils from both sections (No. 759 and 760). He reported high diversity assemblages of dispersed trilete miospores and cryptospores belonging to the Artemopyra brevicosta-Hispanaediscus verrucatus Assemblage Zone. According to Dufka (1995) the occurrences of numerous sporomorphs only in the Svatý Jan Volcanic Centre supports previous sedimentological evidence that this volcanic elevation was emergent during the latest Wenlock. He noted that the ratio of sporomorph and acritarch abundances is very low in samples from section No. 759, but very high for samples from section No. 760, which fits with previous sedimentological interpretation of the Kozel Limestone Member as having been deposited in a very shallow environment (Horný 1955a-c, 1959; Kříž 1992; Kř́ž et al. 1993).

\section{Sampling and methods}

Carbonates from both sections (i.e., No. 759 and 760 of Kř́iž 1992) of the Wenlock Motol Formation were sampled in order to investigate the complete carbon isotope record across the Kozel Limestone Member. This new sampling campaign included 39 carbonate samples for carbon isotope study and covered a stratigraphic interval through the whole thickness of the Kozel Limestone Member in its stratotype (Figs 3, 4, and appendix). 

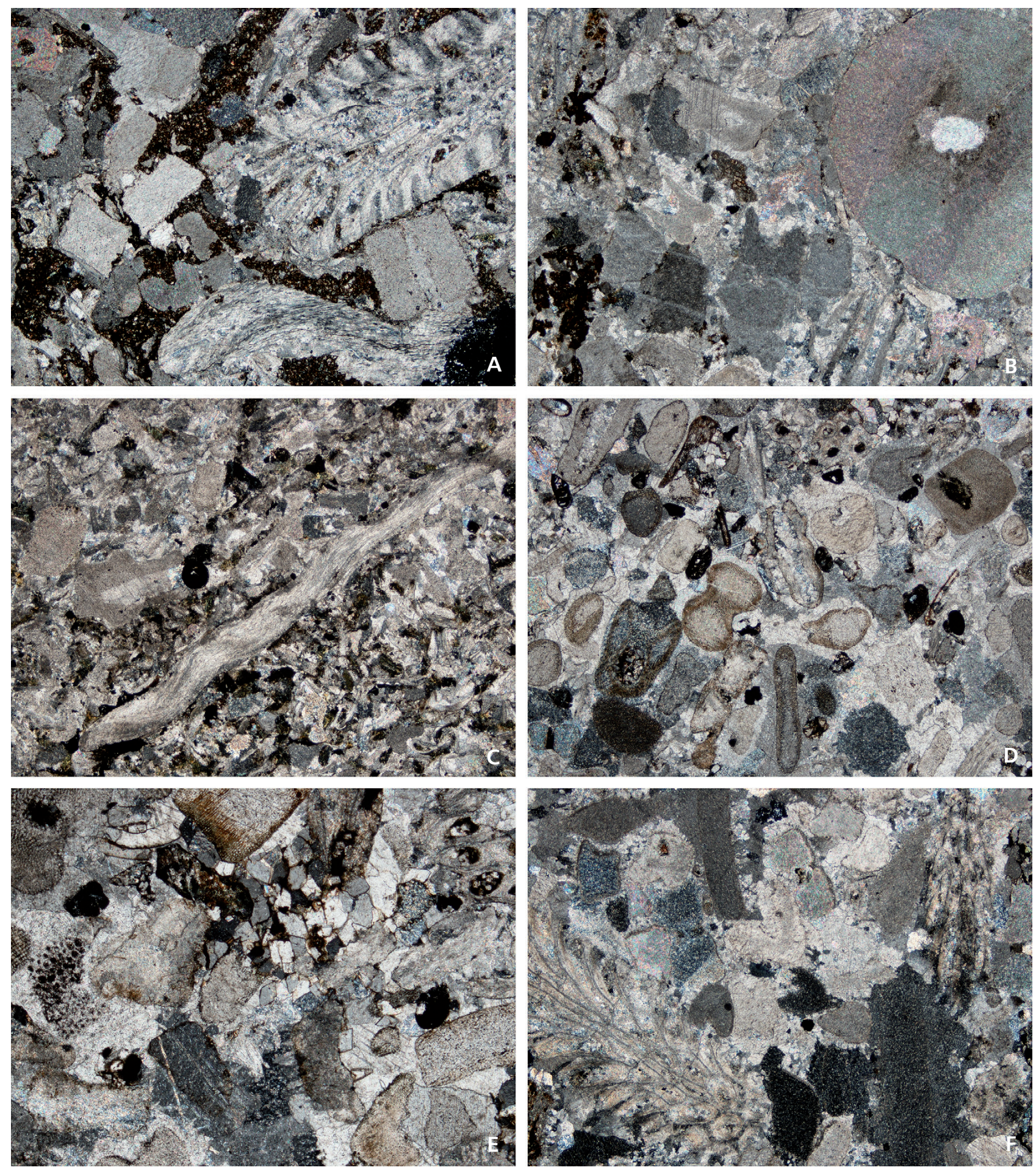

Figure 2. Lithologies of selected levels at the stratotype of the Kozel Limestone Member (section No. 760; bed numbers after Kř́̌ž et al. 1993) - thin sections. $\bullet$ A - crinoid-coral-brachiopod-bryozoan grainstone/rudstone containing small amount of volcanic products; bed No. 24; boundary of R1- and $\mathrm{F} 1-\delta^{13} \mathrm{C}$ chemostratigraphic zones. $\bullet \mathrm{B}-$ mostly crinoid grainstone; bed No. 30b; lower part of the $\mathrm{F} 1-\mathrm{Z}$ - one of the $\delta^{13} \mathrm{C}$ chemostratigraphic zonation. - $\mathrm{C}$ - crinoid-brachiopod grainstone; bed No. 37; the F1-Zone of the $\delta^{13} \mathrm{C}$ chemostratigraphic zonation. $\bullet \mathrm{D}$ - crinoid-bryozoan grainstone showing intensively micritized crinoid columnals rounded by transportation; bed No. 51; upper part of the F1-Zone of the $\delta^{13} \mathrm{C}$ chemostratigraphic zonation. $\bullet \mathrm{E}-$ dolomite crystals in sample about $35 \mathrm{~cm}$ above base of bed No. 51. $\bullet \mathrm{F}$ - crinoid-coral-bryozoan grainstone/rudstone; middle part of bed No. 63; boundary of $\mathrm{R} 2-$ and $\mathrm{F} 2-\delta^{13} \mathrm{C}$ chemostratigraphic zones. 
A few milligrams of rock powder were recovered with a dental drill from cut and polished slabs. Grainstones, rudstones, and packstones represent the dominant limestone lithology of the Kozel Limestone Member (Fig. 2; see the appendix). Where possible, wackestones were sampled, but most analyses were carried out on grainstones. Based on previous study of thin sections, the samples with an occurrence of dolomite were rejected from carbon isotope study (Fig. 2E). The carbonate powder was reacted with $100 \%$ phosphoric acid at $70{ }^{\circ} \mathrm{C}$ using a Gasbench II connected to a Thermo Delta 5 mass spectrometer. All values are reported in \%o relative to $\mathrm{V}-\mathrm{PDB}$ by assigning a $\delta^{13} \mathrm{C}$ value of $+1.95 \%$ and a $\delta^{18} \mathrm{O}$ value of $2.20 \%$ to NSB 19 . Accuracy and precision were controlled by replicate measurements of laboratory standards and were better than $\pm 0.1 \%$ o for both carbon and oxygen isotopes. The nonparametric MannKendall test was used for testing the presence of the monotonic increasing or decreasing trend of $\delta^{13} \mathrm{C}$ values.

\section{Results}

\section{$\delta^{13} \mathrm{C}$ record}

The carbon isotope data are summarized in Figure 3. The carbon isotope composition of carbonates from the two sections is different. The $\delta^{13} \mathrm{C}$ values of the five samples from section No. 759 range from $-1.67 \%$ o to $-0.46 \%$, however the $\delta^{13} \mathrm{C}$ values of 34 samples from the section No. 760 range from $+0.87 \%$ o to $+3.23 \%$ o. A distinct positive two-peaked $\delta^{13} \mathrm{C}$ excursion was found in the $\delta^{13} \mathrm{C}$ record from section No. 760 (Fig. 3). The $\delta^{13} \mathrm{C}$ values rise rapidly from $+1.54 \%$ (bed No. 20) to $+3.23 \%$ (bed No. 24) at the base of section No. 760. It is noteworthy that the $\delta^{13} \mathrm{C}$ values reached such high values over an interval having a thickness of about $1.65 \mathrm{~m}$ (Fig. 2). Four samples from about a $2 \mathrm{~m}$ thick interval (beds No. 28 to No. 30) just above the highest $\delta^{13} \mathrm{C}$ value of the section No. 760 have similar $\delta^{13} \mathrm{C}$ values ranging from $+2.43 \%$ o to $+2.62 \%$ o. The $\delta^{13} \mathrm{C}$ values in the following interval, approximately $20 \mathrm{~m}$ thick (interval from bed No. 31 to bed No. 54), slowly decline to a value of $+0.94 \%$ o. In the subsequent interval, about $24 \mathrm{~m}$ thick, the $\delta^{13} \mathrm{C}$ values steadily increase to value of $+2.62 \%$ (bed No. 63), and again fall to a value of $+0.87 \%$ (bed No. 75 ), forming a distinct second peak of the positive carbon isotope excursion (Fig. 3). The $\delta^{13} \mathrm{C}$ values of samples from the top part of section No. 760, from bed No. 75 to bed No. 86, are rather constant varying around $+1.0 \%$.

\section{Interpretation and discussion}

\section{$\delta^{13} \mathrm{C}$ record}

The newly gathered data from stratotype section of the Kozel Limestone Member (i.e., section No. 760) have revealed a distinct two-peaked positive $\delta^{13} \mathrm{C}$ excursion (see Fig. 3), which occurs within the stratigraphic interval known by the presence of the Homerian carbon isotope excursion. Because of its typical shape (double-peak) as well as its supposed stratigraphic position (i.e., Homerian) we interpret the $\delta^{13} \mathrm{C}$ excursion as the Homerian $\delta^{13} \mathrm{C}$ excursion. The latter isotopic excursion has been hitherto documented from several sections on Baltica (e.g., Wenzel \& Joachimski 1996; Samtleben et al. 1996; Kaljo et al. 1997, 2003, 2007; Kaljo \& Martma 2006; Calner et al. 2006, 2012; Calner 2008), Laurentia (e.g., Lenz 1993; Saltzman 2001; Noble et al. 2005, 2012; Lenz et al. 2006; Cramer et al. 2006, 2010) and Avalonia (e.g., Corfield et al. 1992; Loydell 2007; Ray et al. 2011a, b; Marshall et al. 2012). It is noteworthy that all hitherto recorded occurrences of the Homerian carbon isotope excursion have been described from palaeoplates that subsequently formed the supercontinent Laurussia (i.e., from Laurentia, Baltica and Avalonia). Discovery of the Homerian carbon isotope excursion in peri-Gondwana (Perunica) is thus new evidence for its more widespread and potentially global occurrence.

The carbon isotope excursion can be divided into several distinct geochemical phases that show differing dynamics. This can be used for a definition of chemostratigraphic zones similar to those suggested for the younger mid-Ludfordian carbon isotope excursion (Frýda $\&$ Manda 2013). In contrast to the latter carbon isotope excursion, no long-lasting steady period of high $\delta^{13} \mathrm{C}$ values was observed in the Homerian carbon isotope excursion in either the Barrandian area (Fig. 3) or in other parts of the world.

The course of the Homerian carbon isotope excursion can be divided into two periods of rapid increase in $\delta^{13} \mathrm{C}$ values which are equivalent to the rising limbs of the older (i.e. R1-Zone) and younger (i.e. R2-Zone) peaks and two periods of rapid decrease of $\delta^{13} \mathrm{C}$ values which are equivalent to the falling limbs of the older (i.e. F1-Zone) and younger (i.e. F2-Zone) peaks. As suggested by Frýda \& Manda (2013) the lower and upper boundaries of these chemostratigraphic zones should be defined on the basis of a statistically significant change in the evolution of the $\delta^{13} \mathrm{C}$ record. In case of section No. 760 there is a problem

Figure 3. The $\delta^{13} \mathrm{C}$ record across the two sections (No. 759 and 760 of Kříž 1992) of the Motol Formation showing the late Wenlock Homerian $\delta^{13} \mathrm{C}$ excursion. Distribution of Silurian rocks in the Barrandian area (Perunica), including the position of the studied sections as well as the $\delta^{13} \mathrm{C}$ chemostratigraphic zonation of section No. 760, are shown (right). Section modified after Kříž et al. (1993). 


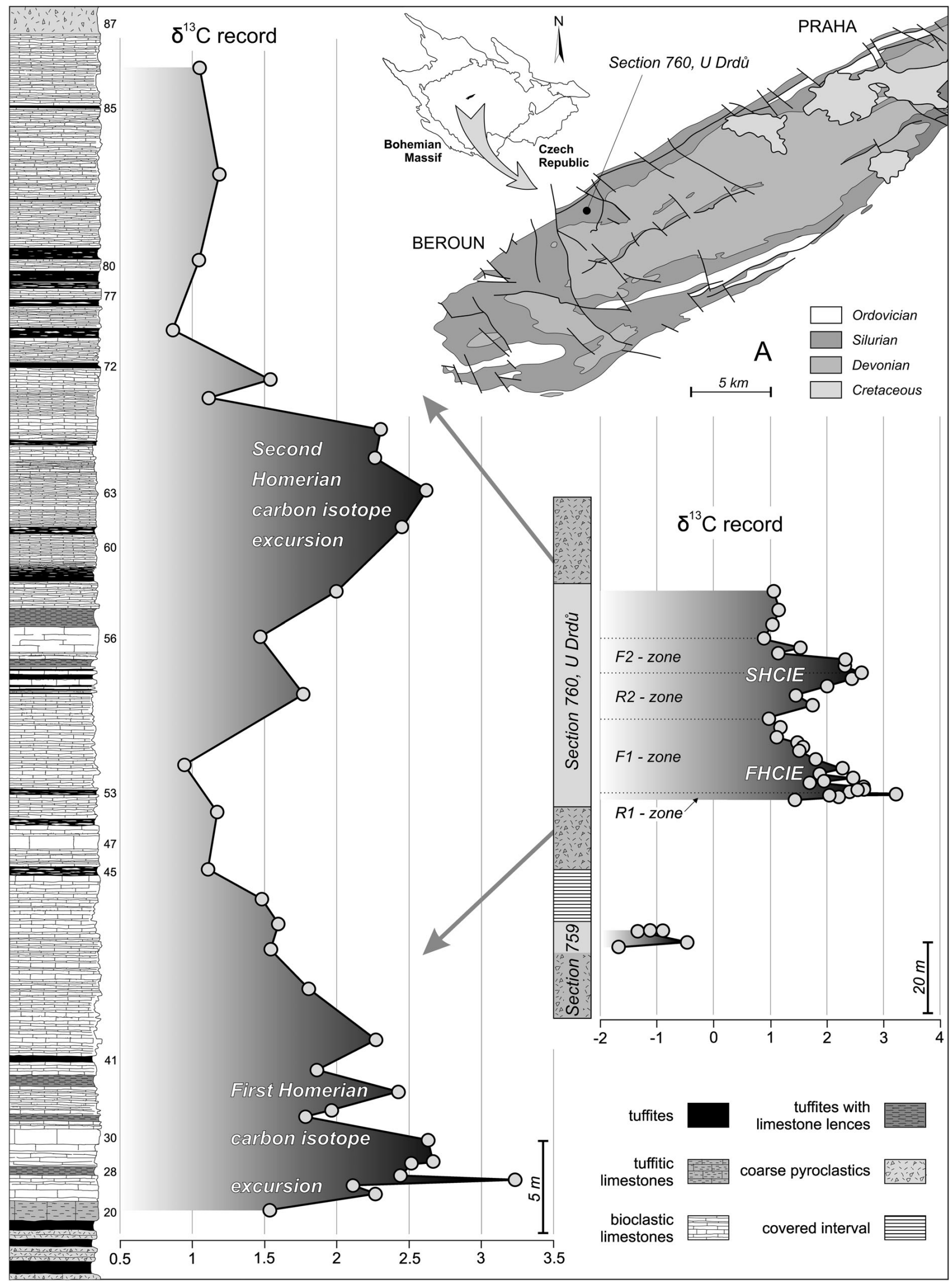


with using this definition for the R1-zone because of the low number of measured $\delta^{13} \mathrm{C}$ values (see Fig. 3) and thus only the boundary between the R1- and F1-zones is defined. The nonparametric Mann-Kendall test reveals statistically significant decreasing trends of $\delta^{13} \mathrm{C}$ values for the F1- and F2- zones and statistically significant increasing trends of $\delta^{13} \mathrm{C}$ values for the $\mathrm{R} 2$-Zone $(\mathrm{p}<0.05$ in all cases).

At the present state of knowledge all carbonate beds of section No. 760 up to bed No. 25 (of Kříž et al. 1993) belong to the $\delta^{13} \mathrm{C}$ chemostratigraphic R1-Zone of the Homerian carbon isotope excursion. The mostly carbonate sequence between bed No. 25 and the lower part of bed No. 54 belongs to the $\delta^{13} \mathrm{C}$ chemostratigraphic F1-Zone and that between beds No. 54 and No. 63 to the R2-Zone. The chemostratigraphic F2-Zone starts within bed No. 63 and ends roughly at bed No. 75 (Figs 3, 4).

It is noteworthy that the precise position of the chemostratigraphic boundaries, as with biostratigraphic boundaries, depends on sampling density. The present $\delta^{13} \mathrm{C}$ chemostratigraphy of section No. 760 is based on only 34 measurements and it is thus evident that the chemostratigraphic resolution of this section may be improved in future by additional sampling.

\section{Kozel Limestone Member}

The Kozel Limestone Member (see appendix for its definition and a list of its older informal names) is restricted to the Central Segment of the Prague Basin (Křŕž 1992). Its stratotype as well as parastratotype sections represent the most important late Wenlock fossil localities of the Barrandian having been known since the first half of the nineteenth century. During the last 200 years this limestone succession has yielded many tens of fossil species including mainly brachiopods, corals, trilobites, gastropods, cephalopods, and bivalves. Many of those species are known only from this limestone unit or have it as its type locality. In addition, some fossil groups (e.g., stromatoporoids) have never been studied and others have not been revised during the last 100 years (e.g., gastropods). Because of its very rich fossil record, establishing the age of the Kozel Limestone Member has been the subject of many studies during the last century (e.g., Kodym et al. 1931; Bouček 1934; Havlíček et al. 1958; Horný 1955a-c, 1962, 1965, 1971; Havlíček \& Štorch 1990, 1999; Kříž 1991, 1992, 1998; Kříž et al. 1993; Havlíček 1995; Dufka 1995; and Manda 1996). In the following paragraphs the stratigraphic significance of all hitherto available biostratigraphic data from sections No. 759 and 760 is briefly discussed and a new, more detailed zonation of the Kozel Limestone Member based on $\delta^{13} \mathrm{C}$ chemostratigraphy is proposed.

\section{Graptolites}

Kříž (1992) and Kříž et al. (1993) analysed the available biostratigraphic data useful for dating of the Kozel Limestone Member. They mentioned that the graptolite M. flemingii is the last graptolite found below its base at the top of section No. 759. The youngest occurrence of this graptolite is recorded in the C. lundgreni Biozone (Štorch 1994). Because of this biostratigraphic datum Kříž (1992) concluded that the age of the Kozel Limestone Member could correspond to the period between the $P$. dubius parvus Biozone and the $M$. vulgaris Biozone (= M. ludensis Biozone). Manda (1996) mentioned the occurrence of Cyrtograptus lundgreni and Cyrtograptus cf. perneri Bouček, 1933 (det. P. Storch) in the lower part of section No. 759 and concluded that "if the species is really Cyrtograptus perneri, it would indicate the time inverval between the last occurrence of the species Cyrtograptus radians and the first occurrences of Testograptus testis (assemblage zone Cyrtograptus lundgreni - Štorch 1994)". The latter conclusion is, however, somewhat inaccurate because the cooccurrence of Cyrtograptus lundgreni, Cyrtograptus perneri and Monograptus flemingii is well known from the base of the Cyrtograptus lundgreni Biozone onwards (e.g., Lenz \& Melchin 1989, Štorch 1994, Williams \& Zalasiewicz 2004). Nevertheless the finding of Cyrtograptus cf. perneri may suggest a narrower stratigraphic interval for the beds in the lower part of section No. 759 than the previously reported occurrence of $M$. flemingii. The latter species is known to disapear at the end of Cyrtograptus lundgreni Biozone, thus later than Cyrtograptus perneri (e.g., Štorch 1994). Taken together, the present limited graptolite data from section No. 759 provide evidence for its placement within the Cyrtograptus lundgreni Biozone, as already noted by Kř́žz (1992).

\section{Conodonts}

Kříž (1992) and Kříž et al. (1993) noted the occurrence of three conodont species from section No. 759. Ozarkodina s. sagitta was found in its lower part and Ozarkodina ex. excavata and Kockelella absidata in the upper part. One conodont species, Ozarkodina bohemica, was reported from nine conodont samples (beds No. 24, 28, 30, 40 top, 70 bottom, 73 bottom, 82 top, 86 centre and 86 top) from section No. 760 (Kř́iž 1992). Murphy et al. (2004) recently transferred Ozarkodina excavata to a new conodont genus Wurmiella, but this taxonomical placement was later rejected by Suttner (2007). The stratigraphic range of the Wurmiella (= Ozarkodina) excavata is rather long, from the Wenlock to the Lochkovian (e.g., Corradini \& Corriga 2012) and so its occurrence in section No. 759 is of low biostratigraphic significance. On the other hand, the other conodont species, Ozarkodina s. sagitta and Kockelella 

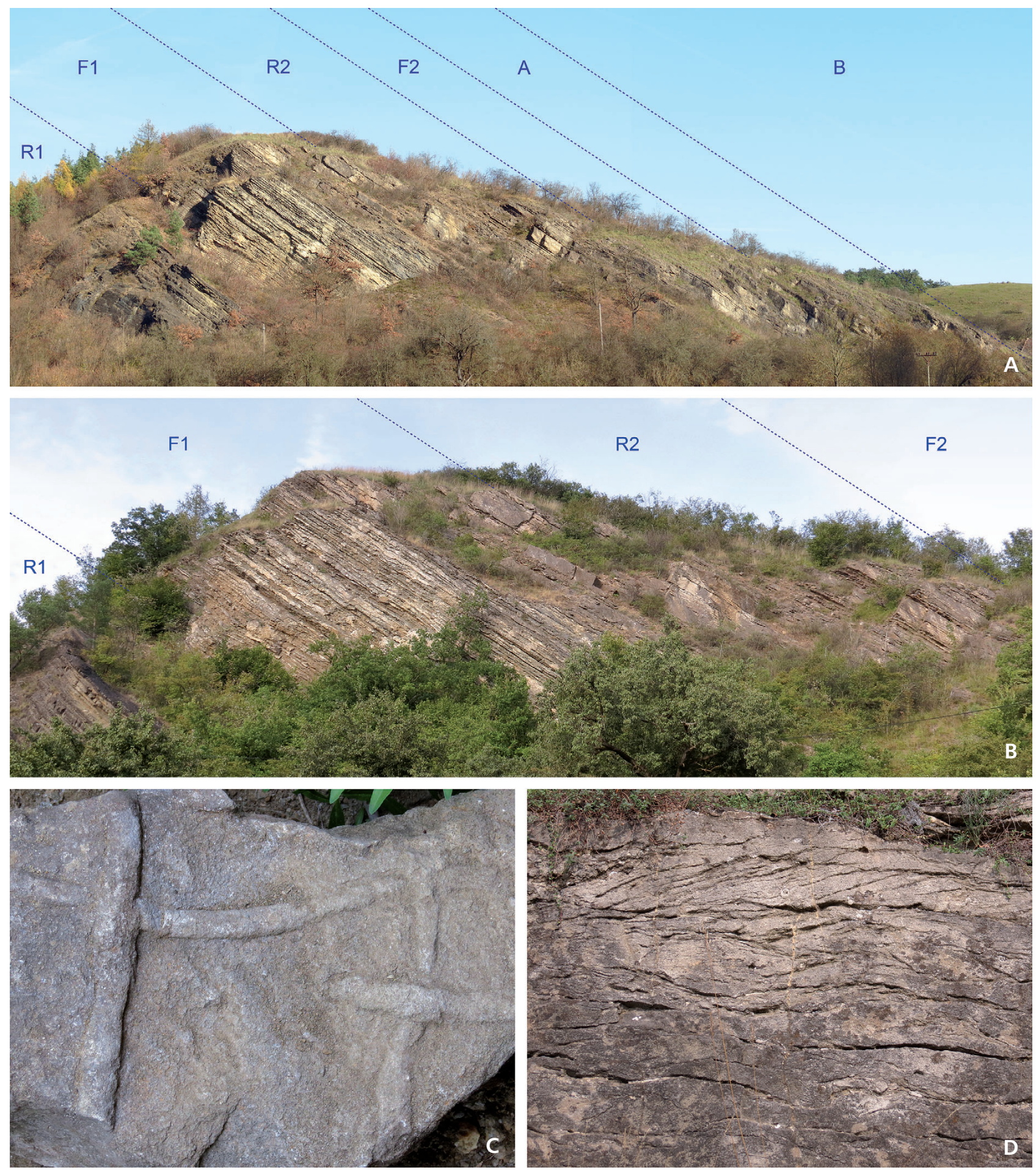

Figure 4. Stratotype of the Kozel Limestone Member (section No. 760). A - complete view showing its $\delta^{13} \mathrm{C}$ chemostratigraphic zonation (R1-, F1-, R2-, and F2-zones). Interval marked as A represents upper part (about $15 \mathrm{~m}$ ) of the limestone succession of the Kozel Limestone Member above the Homerian $\delta^{13} \mathrm{C}$ excursion. Interval marked as B corresponds to the volcanic unit overlying the Kozel Limestone Member. $\bullet$ B detailed view of the lower part of section No. 760 . $\bullet$ - sample from the middle part of the F1-Zone with traces of the ichnogenus Palaeophycus (det. R. Mikuláš, Prague) which occurs mostly in the shallow water Cruziana ichnofacies. D - view of bed No. 63 showing cross-bedding in the shallow water limestones. 
absidata, reported from section No. 759 are biostratigraphically more significant. The FAD of Ozarkodina s. sagitta corresponds roughly to the base of the $C$. lundgreni Biozone and the latter conodont species became extinct before the end of the C. lundgreni Biozone (Jeppsson \& Calner 2003, Loydell et al. 2010, Cramer et al. 2011). On the other hand, the conodont Kockelella absidata suggests a much younger age. Jeppsson in Calner \& Jeppsson (2003) placed Kockelella absidata into the species K. ortus (Walliser) as its subspecies Kockelella ortus absidata. The FAD of $K$. ortus absidata occurs at the base (Calner \& Jeppsson 2003) or within (Cramer et al. 2011) the Colonograptus deubeli-Colonograptus praedeubeli graptolite Biozone. Thus the occurrence of Ozarkodina s. sagitta in the basal part of section No. 759 suggests an age corresponding to the C. lundgreni Biozone. However, K. ortus absidata from the upper part of section No. 759 (Kř́íz 1992) suggests an age corresponding to the $K$. ortus absidata conodont Biozone or to the Colonograptus deubeli-C. praedeubeli or younger graptolite biozones (see Cramer et al. 2011).

Ozarkodina bohemica, the only conodont species found in section No. 760, is a long-ranging taxon known from the lower Wenlock to lower Ludlow (Calner \& Jeppsson 2003, Jeppsson et al. 2006). Jeppsson in Calner \& Jeppsson (2003) established a new subspecies, Ozarkodina bohemica longa, within the morphological range of Ozarkodina bohemica. However, there are no published data as to which subspecies the specimens from section No. 760 belong. Thus the occurrence of Ozarkodina bohemica in beds No. 24 to 86 of section No. 760 is suggesting only that age of the latter beds is somewhere between early Wenlock and early Gorstian. But, if the determination of Kockelella absidata $(=K$. ortus absidata) from the underlying section (No. 759) is correct, than a "conodont age" for section No. 760 should correspond to the interval from the Colonograptus deubeliC. praedeubeli Biozone to the early Gorstian.

\section{Organic microfossils}

Dufka (1995), based on his analysis of organic microfossils, concluded that the age of the limestone succession of section No. 760 is latest Wenlock. He noted also that Synorisporites? libycus, which he found in 13 samples from section No. 760 (from bed No. 31 to 86), has been recorded only from the younger Synorisporites libycusLophozonotriletes poecilomorphus Biozone of Ludlow age. Dufka (1995) interpreted the occurrence of this taxon as evidence for its early origin in the Artemopyra brevicosta-Hispanaediscus verrucatus Assemblage Zone. In his figure 2 Dufka (1995) suggested a possible zonation of sections No. 759 and 760 . According to him, all beds in section No. 759 and the basal tufitic part of section No. 760 are equivalent to the Cyrtograptus lundgreni Biozone. The first limestone beds of stratotype section (No. 760), up to the level around bed No. 35 could belong to $P$. dubius parvus Biozone. An interval above bed No. 35 is suggested to be equivalent to "levels with G. nassa". The top of section No. 760 he placed in the $M$. vulgaris (=ludensis) Biozone. However, it is noteworthy that the internal division of section No. 760 suggested by Dufka (1995, fig. 2) is not supported by any biostratigraphic data. It is noteworthy that the organic microfossils do not exclude even an early Gorstian (Ludlow) age for the upper part of section No. 760 (see Burgess \& Richardson 1991, 1995; Beck \& Strother 2001, 2008; Steemans et al. 2012).

\section{Age of the Kozel Limestone Member inferred from biostratigraphy}

Precise biostratigraphic dating of the Kozel Limestone Member is difficult because of a lack of biostratigraphically significant fossils. Also, interpretation of the biostratigraphic data from the underlying sequence forming section No. 759 is not easy. As shown above, the graptolite data (i.e., P. dubius s.l., M. flemingii, C. lundgreni and C. cf. perneri) indicates the Cyrtograptus lundgreni Biozone (Turek 1990, Štorch 1994, Manda 1996); however, the conodont data suggest a much younger age $(K$. ortus absidata conodont Biozone) being equivalent to the Colonograptus praedeubeli-Colonograptus deubeli Biozone or younger graptolite biozones. Thus conodont and graptolite data from section No. 759 seem to be in conflict, but we hope that on-going conodont and organic microfossil sampling will solve this problem in near future.

\section{Age of the Kozel Limestone Member inferred from lithostratigraphy}

The approximately $60 \mathrm{~m}$ thick limestone sequence of section No. 760 was deposited during a period of low volcanic activity within the Svatý Jan volcanic centre. The latter limestone sequence is underlain and overlain by thick units of volcanic rocks which were formed during main activity of the Svatý Jan Volcano (see details and references in Kř́̌ž 1992 and Kříž et al. 1993). According to Kříž (1998, p. 90), "Evidence for the age of the main activities of the Svatý Jan Volcano can be interpreted from two levels of tuffites (redeposited tuffs) more than $1 \mathrm{~m}$ thick that occur in the sequence of shale in the Všeradice Section (the Southern Segment) just below the base of the M. dubius parvus Biozone and at the base of the $C$. colonus Biozone. The shales between these two levels at Všeradice most probably represent an equivalent of the quiet phase of the Svatý Jan Volcano when the Kozel Limestone Complex (= Kozel Limestone Member) was deposited in the Svatý Jan Volcanic Centre area." 


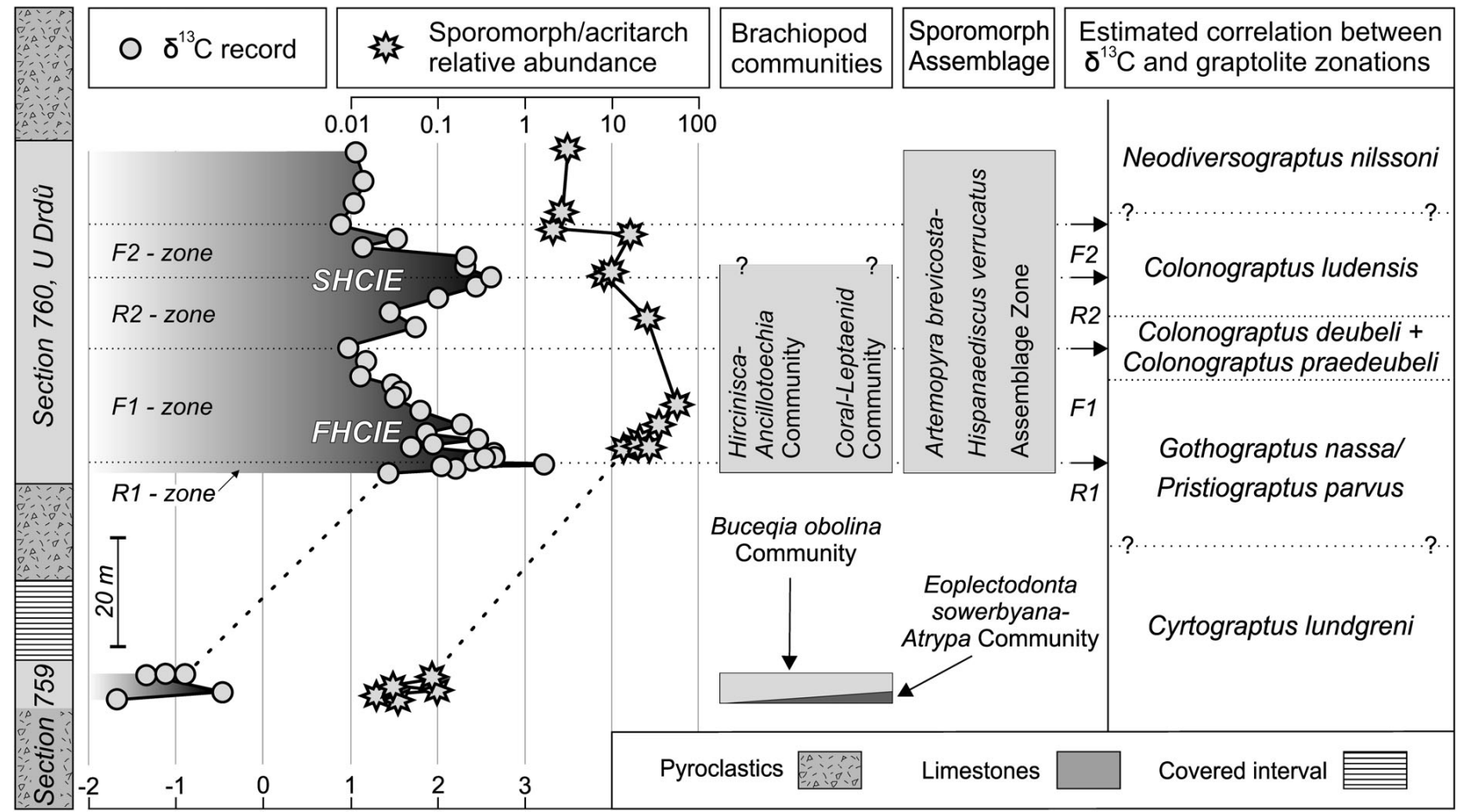

Figure 5. Diagram showing the $\delta^{13} \mathrm{C}$ chemostratigraphic zonation, sporomorph/acritarch relative abundance (based on data from Dufka 1995), stratigraphic distribution of brachiopod communities, and estimated correlation between the $\delta^{13} \mathrm{C}$ chemostratigraphic and graptolite zonations.

New research by Kozłowska-Dawidziuk et al. (2001) at the Všeradice section, however, revealed more complex relationships. The stratigraphic position of the first tuffitic bed (i.e., just below the base of the Pristiograptus parvusGothograptus nassa Biozone) was confirmed. KozłowskaDawidziuk et al. (2001) reported the occurrence of an additional thin tuffitic bed (about $25 \mathrm{~cm}$ thick) within the upper third of the Colonograptus deubeli-C. praedeubeli Biozone. A third tuffitic bed (about $1.2 \mathrm{~m}$ thick) lies within the lower Ludlow Neodiversograptus nilssoni Biozone (about $1 \mathrm{~m}$ above its base; see fig. 2 in Kozłowska-Dawidziuk et al. 2001). Based on this new data, if we accept the stratigraphic correlation suggested by Křřž (1998), this suggests that the youngest part of the Kozel Limestone Member may be of the earliest Gorstian age (Ludlow).

\section{Age of the Kozel Limestone Member inferred from $\delta^{13} \mathrm{C}$ chemostratigraphy}

Even though the Homerian $\delta^{13} \mathrm{C}$ excursion was firstly described more that 20 years ago (Corfield et al. 1992), its correlation with the global Silurian chronozones is still not completely established. The main reason for this situation is the fact that the majority of records of the Homerian $\delta^{13} \mathrm{C}$ excursion have been described from limestone successions, which generally lack graptolites. The current Silurian timescale assumes a correlation between stage boundaries and graptolite zones and because of that a correlation of graptolite-lacking successions to the global Silurian chronostratigraphic zonation is often difficult (Cramer et al. 2006; Loydell 1998, 2007, 2012; Loydell et al. 2010). Cramer et al. $(2011,2012)$ summarized recent knowledge on correlation of the Homerian $\delta^{13} \mathrm{C}$ excursion with the graptolite and conodont zonations. They showed that the first peak of the two-peaked Homerian $\delta^{13} \mathrm{C}$ excursion occurs within the Ozarkodina bohemica longa Biozone and the second peak in the Kockelella ortus absidata Biozone. These conodont biozones have, however, rather long stratigraphic ranges, the first approximately from upper part of $C y r t o$ graptus lundgreni graptolite Biozone to about base of $\mathrm{Co}$ lonograptus deubeli-C. praedeubeli graptolite Biozone. The following younger Kockelella ortus absidata conodont Biozone ends close to the base of Ludlow Series (Cramer et al. 2011). Correlation of the Homerian $\delta^{13} \mathrm{C}$ excursion with the more precise graptolite zonations is not without problems (compare data from Kaljo et al. 2007; Cramer et al. 2006, 2011; Noble et al. 2012). Some uncertainties are probably influenced by a low density of chemostratigraphic and/or biostratigraphic samples, by different local graptolite zonations (Kaljo \& Martma 2006; Lenz et al. 2006; Loydell 2007, 2012; Noble et al. 2005) and maybe also by not exactly synchronous appearances of zonal graptolite taxa in different areas of Laurentia, Avalonia and Baltica (e.g., Loydell 1998, 2007; Cramer et al. 2006, 2011; Noble et al. 2005, 2012; Marshall et al. 2012). 
Present summaries of the stratigraphic position of the Homerian $\delta^{13} \mathrm{C}$ excursion (Cramer et al. 2011) suggest that the excursion started in the uppermost part of the Cyrtograptus lundgreni Biozone, reaches its maximum within the Pristiograptus parvus-Gothograptus nassa Biozone and ends within the Colonograptus deubeliC. praedeubeli Biozone. In the upper part of the latter graptolite biozone the $\delta^{13} \mathrm{C}$ values start to rise to their second peak, which is reached within the Colonograptus ludensis graptolite Biozone. The excursion ends before the end of the latter biozone (but see also Marshall et al. 2012).

Published data suggest the following correlation of the graptolite zonation with the $\delta^{13} \mathrm{C}$ chemostratigraphic zonation of the Homerian $\delta^{13} \mathrm{C}$ excursion (Fig. 5). The chemostratigraphic R1-Zone ranges from the uppermost part of the Cyrtograptus lundgreni Biozone to about the middle of the P. parvus-G. nassa Biozone and the following F1-Zone ends within the $C$. deubeli-C. praedeubeli Biozone. The chemostratigraphic R2-Zone ranges from the C. deubeli-C. praedeubeli Biozone to about the middle of the $C$. ludensis Biozone and the following F2-Zone ends before the base of the Ludlow Series. Nevertheless it is noteworthy that precise correlation of the graptolite and $\delta^{13} \mathrm{C}$ chemostratigraphic zonation still needs more densely spaced sampling from different sections globally. At present, the local records of Silurian carbon isotope excursions may appear vary as a result of such factors as sample spacing, stratigraphic completeness, and sediment accumulation rate (e.g., Sadler 2012).

If the above-mentioned correlation is used as a preliminary estimation, the following internal stratigraphic zonation of the studied sections may be proposed. The low $\delta^{13} \mathrm{C}$ values from limestone beds of section No. 759 suggest that their age is older than the uppermost part of the Cyrtograptus lundgreni Biozone, what is in a good agreement with published graptolite data (Kř́ž 1992, Kříž et al. 1993, Manda 1996), but partly in conflict with conodont data (see above).

The new chemostratigraphic data enable also more precise stratigraphic correlation within the stratotype section of the Kozel Limestone Member (section No. 760) than that based on available biostratigraphic data (see discussion above). The basal part of section No. 760 up to bed No. 25 (of Krríz et al. 1993) belongs to the top of the $\delta^{13} \mathrm{C}$ chemostratigraphic R1-Zone and its most probable age corresponds to the P. parvus-G. nassa Biozone (Figs 3, 4, and 5). The succeeding, mostly carbonate sequence between bed No. 25 and bed No. 54 belongs to the $\delta^{13} \mathrm{C}$ chemostratigraphic F1-Zone and thus it should correspond to interval from the upper part of the P. parvus-G. nassa Biozone and lower part of the $C$. deubeli-C. praedeubeli Biozone. The beds from No. 54 to No. 63 (i.e., the R2-Zone of the Homerian carbon isotope excursion) correspond to the upper part of C. deubeli-C. praedeubeli Biozone and lower part of the Cyrtograptus ludensis Biozone. The bed from No. 63 to roughly bed No. 75 (the chemostratigraphic F2-Zone) corresponds to the same graptolite biozone (i.e., to the Cyrtograptus ludensis Biozone).

The age of the upper approximately $15 \mathrm{~m}$ of section No. 760 is not certain. The second peak of the Homerian $\delta^{13} \mathrm{C}$ excursion ends in the majority of published $\delta^{13} \mathrm{C}$ records just below the base of the Ludlow Series or even above its base (see discussion in Marshall et al. 2012). The $\delta^{13} \mathrm{C}$ values of limestones from the upper approximately $15 \mathrm{~m}$ of section No. 760 (Fig. 3) vary by about $+1 \% o$ and seem to belong to typical post-peak values. If so then the age of the uppermost part of section No. 760 may correspond to the lowermost Gorstian. On the other hand, the uppermost part of the section No. 760 has been interpreted as belonging to top of the Homerian by all previous researchers. However, at present there is no biostratigraphic evidence from this part of the section, which demonstrates its Homerian age and rejects the Gorstian age. Nevertheless the question of the age of the upper part of section No. 760 is not yet solved and needs in the future more detailed study.

\section{Homerian bioevents and the Hircinisca-Ancillotoechia brachiopod Community}

The graptolite extinction event within the Homerian was one of the first recognized Silurian bioevents (Jaeger 1959, 1991). During this bioevent, known as "Große Krise" or lundgreni Bioevent, up to $95 \%$ of all graptolite species became extinct in some regions and the crisis involved also other planktonic groups such as acritarchs, prasinophytes and radiolarians (e.g., Koren' 1991; Štorch 1995; Kaljo et al. 1996; Lenz \& Kozłowska-Dawidziuk, 2001, 2002; Porębska et al. 2004; Lenz et al. 2006; Noble et al. 2005, 2012). Study of conodont faunas revealed distinct crises known as the Mulde bioevent (Jeppsson et al. 1995, Calner \& Jeppsson 2003, Jeppsson \& Calner 2003, Calner et al. 2006). Loydell (2007) showed that the Mulde Event conodont extinctions precede the dramatic graptolite extinction (i.e., the "Große Krise" or lundgreni Bioevent), sea-level fall and positive $\delta^{13} \mathrm{C}$ Homerian excursion. Published data suggest that two regressive episodes during the mid to late Homerian were recorded in many areas. The onset of the first regression occurred late in the Cyrtograptus lundgreni Biozone with the lowest sea-level in the early part of the Gothograptus nassa Biozone and the second regression occurred just before or within the Colonograptus ludensis Biozone (e.g., Loydell 1998, 2007; Calner \& Jeppsson 2003; Johnson 2006; Noble et al. 2012). Organic microfossil data from sections No. 759 and 760 suggests a similar pattern (Fig. 5). Relative sporomorph/acritarch abundance plotted on a logarithmic scale suggests its great variability. The highest terrestrial input inferred from the highest 
values of relative sporomorph/acritarch abundance occurred in the $\delta^{13} \mathrm{C}$ chemostratigraphic F1-Zone which corresponds to the upper part of the P. parvus-G. nassa or lower part of $C$. deubeli-C. praedeubeli graptolite biozones. During the F1-Zone the relative abundance of sporomorphs is about 1000 times higher than during deposition of the underlying section, No. 759 (Fig. 5). Stricanne et al. (2006), who analysed palynological signals across the mid-Ludfordian carbon isotope excursion (Ludlow, Silurian) on Gotland reported similar pattern.

The Homerian conodont extinction interval occurs within the upper part of the Cyrtograptus lundgreni Biozone before the sea-level fall at which time the main graptolite extinction occurred. According to Cramer et al. (2012), the overlying Gothograptus nassa Biozone represents an interval with the surviving fauna, and the younger biozones (i.e., C. deubeli-C. praedeubeli and C. ludensis) represent the eventual recovery and re-radiation following the biotic event. Cramer et al. (2012, fig. 9) suggested that the $C$. deubeli-C. praedeubeli Biozone corresponds to an interval when new species originated from surviving lineages, and during the younger $C$. ludensis Biozone a major radiation of new lineages occurred.

In this context, the age of the very diverse Hircinisca-Ancillotoechia brachiopod Community known from the Kozel Limestone Member is somewhat surprising. This brachiopod community includes about 50 brachiopod species and even more species of other benthic groups (Barrande's locality Kozel). Only about $10 \%$ of the 50 brachiopod species belong to surviving species known from older units (see Havlíček \& Štorch 1990, 1999; Havlíček 1995). These facts suggest that the Hircinisca-Ancillotoechia brachiopod Community does not represent a surviving fauna, but a new brachiopod fauna. The $\delta^{13} \mathrm{C}$ chemostratigraphy has revealed that the appearance of the high diversity Hircinisca-Ancillotoechia Community was in the uppermost part of the R1-Zone, that corresponds to the lower part of the $P$. parvus-G. nassa Biozone. Thus the origin of a new high diversity fauna in the Barrandian area fits with a post-crisis period during low sea-level, but occurs long before the presumed recovery during the $C$. ludensis Biozone (see Cramer et al. 2012; see here Fig. 5). Faunal elements of the Hircinisca-Ancillotoechia Community have been documented also in younger strata of section No. 760 up to bed No. 60 (Kř́ž 1992, Kříž et al. 1993, Havlíček 1995). Bed No. 60 corresponds to the highest value of the second peak of the Homerian $\delta^{13} \mathrm{C}$ excursion and so to the $C$. ludensis Biozone (Figs 3, 4). The stratigraphic range of the Hircinisca-Ancillotoechia Community is thus rather long (from the P. parvus$G$. nassa Biozone to the $C$. ludensis Biozone) including the survival and recovery intervals of Cramer et al. (2012). The present data from the Barrandian thus suggest that recovery of benthic faunas after the series of mid-Homerian extinc- tion events (i.e., the Mulde conodont and the lundgreni graptolite bioevents) started much earlier than has hitherto been described from other world areas.

\section{Conclusions}

New $\delta^{13} \mathrm{C}$ data across the Kozel Limestone Member have highlighted several new aspects that are of importance for both regional and global stratigraphic correlations as well as for increased understanding of the late Wenlock Homerian carbon isotope excursion. The main conclusions are summarized below:

1. The newly collected $\delta^{13} \mathrm{C}$ data provide for the first time evidence for the Homerian (late Wenlock) positive carbon isotope excursion in peri-Gondwana. In addition, our data present the first evidence for this isotope excursion outside of palaeocontinents that later formed the supercontinent Laurussia (Fig. 1).

2. The $\delta^{13} \mathrm{C}$ excursion may be divided into four distinct geochemical phases having different $\delta^{13} \mathrm{C}$ dynamics. The Homerian positive carbon isotope excursion has a characteristic double-peak (Fig. 3), which consists of two periods when $\delta^{13} \mathrm{C}$ values increased significantly as well as two periods when these values declined significantly. These time periods are used herein to define a new $\delta^{13} \mathrm{C}$ chemostratigraphic zonation (R1-, F1-, R2-, and $\mathrm{F} 2$-zones) of the Homerian positive carbon isotope excursion. The newly established $\delta^{13} \mathrm{C}$ chemostratigraphic zonation may be used for future improvement of intercontinental correlations and for integration of the graptolite and conodont biostratigraphic zonations with the $\delta^{13} \mathrm{C}$ chemostratigraphy.

3. Application of $\delta^{13} \mathrm{C}$ chemostratigraphy considerably improves the stratigraphic resolution within the Kozel Limestone Member and enables more precise dating of its highly diverse fauna. The present data reveal that the recovery of benthic communities after the series of mid-Homerian extinction events (i.e., the Mulde conodont and the lundgreni graptolite bioevents) started much earlier than has been hitherto described from other world occurrences.

\section{Acknowledgements}

This paper is a contribution to IGCP 591 and IGCP 596. The research was supported by a grant from the Grant Agency of the Czech Republic (GAČR 210/12/2018), and a grant from the Czech Geological Survey (334600). We thank Jiři Křǐž (Prague) for the provision of his unpublished field data on section No. 760, copies of rare publications and for fruitful discussion. We are indebted to Emilia Jarochowska (Erlangen) for useful papers and discussion and to David K. Loydell (Portsmouth) for valuable suggestions, 
constructive comments and linguistic improvement. The paper greatly benefited from reviews by Alex Munnecke (Erlangen) and Petr Štorch (Prague) that significantly improved the manuscript.

\section{References}

BARRAnde, J. 1852-1881. Systême silurien du Centre de la Bohême. Privately published, Prague \& Paris.

BeCK, J.H. \& STRotheR, P.K. 2001. Silurian spores and cryptospores from the Arisaig Group, Nova Scotia, Canada. Palynology 25, 127-177. DOI 10.2113/0250127

BeCK, J.H. \& StROTHER, P.K. 2008. Spores and cryptospores from a Silurian section near Allenport, Pennsylvania. Journal of $\mathrm{Pa}$ leontology 82(5), 857-883. DOI 10.1666/08-009R.1

BouČEK, B. 1933. Monographie der obersilurischen Graptoliten aus der Familie Cyrtograptidae. Travaux de l'Institut de Géologie et de Paléontologie de l'Université Charles à Praha (Prague) 1, 1-84.

BouČEK, B. 1934. Bemerkungen zur Stratigraphie des böhmischen Gotlandien und seinen Faziesverhältnissen. Centralblatt für Mineralogie, Geologie und Palaeontologie, Abteilung B 11, 477-494.

BOUČEK, B. 1953. Biostratigraphy, development and correlation of the Želkovice and Motol Beds of the Silurian of Bohemia. Sborník Ústředního ústavu geologického, Oddíl paleontologický 20, 421-484.

Buggisch, W. \& Mann, U. 2004. Carbon isotope stratigraphy of Lochkovian to Eifelian limestones from the Devonian of central and southern Europe. International Journal of Earth Sciences 93, 521-541.

Burgess, N.D. \& Richardson, J. B. 1991. Silurian cryptospores and miospores from the type Wenlock area, Shropshire, England. Palaeontology 34, 601-628.

Burgess, N.D. \& Richardson, J.B. 1995. Late Wenlock to early Pridoli cryptospores and miospores from south and southwest Wales, Great Britain. Palaeontographica 236, 1-44.

CALner, M. 2008. Silurian global events - at the tipping point of climate change, 21-58. In Ashraf, M.T. (ed.) Mass extinctions. Springer-Verlag, Berlin \& Heidelberg.

DOI 10.1007/978-3-540-75916-4_4

Calner, M. \& Jeprsson, L. 2003. Carbonate platform evolution and conodont stratigraphy during the middle Silurian Mulde Event, Gotland, Sweden. Geological Magazine 140(2), 173-203. DOI 10.1017/S0016756802007070

Calner, M., Kozlowska, A., Masiak, M. \& Schmitz, B. 2006. A shoreline to deep basin correlation chart for the middle Silurian coupled extinction-stable isotopic event. GFF 128, 79-84. DOI 10.1080/11035890601282079

Calner, M., Lehnert, O. \& Jeppsson, L. 2012. New chemostratigraphic data through the Mulde Event interval (Silurian, Wenlock), Gotland, Sweden. GFF 134, 65-67. DOI 10.1080/11035897.2012.670015.

Corfield, R.M., Siveter, D.J., Cartlidge, J.E. \& McKerrow, W.S. 1992. Carbon isotope excursion near the Wenlock-Ludlow (Silurian) boundary in the Anglo-Welsh area. Geology 20, 371-374. DOI 10.1130/0091-7613(1992)020<0371:CIENTW>2.3.CO;2

Corradini, C. \& Corriga, M.G. 2012. A Přídolí-Lochkovian conodont zonation in Sardinia and the Carnic Alps: implications for a global zonation scheme. Bulletin of Geosciences 87(4), 635-650. DOI 10.3140/bull.geosci.1304
Cramer, B.D., Brett, C.E., Melchin, M.J., Männik, P., KlefFner, M.A., McLaughlin, P.I., Lloydell, D.K., Munnecke, A., Jeppsson, L., Corradini, C., Brunton, F.R. \& Saltzman, M.R. 2011. Revised correlation of Silurian provincial series of North America with global and regional chronostratigraphic and $\delta^{13} \mathrm{C}_{\text {carb }}$ chemostratigraphy. Lethaia $44,185-202$. DOI 10.1111/j.1052-3931.2010.00234.x

Cramer, B.D., Condon, D.J., Söderlund, U., Marshall, C., Worton, G.J., Thomas, A.T., Calner, M., Ray, D.C., Perrier, V., Boomer, I., Patchett, P.J. \& Jeppsson, L. 2012. $\mathrm{U}-\mathrm{Pb}$ (zircon) age constraints on the timing and duration of Wenlock Silurian) paleocommunity collapse and recovery during the "Big Crisis". Geological Society of America Bulletin 124, 11-12, 1841-1857. DOI 10.1130/B30642.1

Cramer, B.D., Kleffner, M.A., Brett, C.E., McLaughlin, P.I., Jeppsson, L., Munnecke, A. \& Samtleben, C. 2010. Paleobiogeography, high-resolution stratigraphy, and the future of Paleozoic biostratigraphy: Fine-scale diachroneity of the Wenlock (Silurian) conodont Kockelella walliseri. Palaeogeography, Palaeoclimatology, Palaeoecology 294, 232-241. DOI 10.1016/j.palaeo.2010.01.002

Cramer, B.D., Kleffner, M.A. \& Saltzman, M.R. 2006. The late Wenlock Mulde positive carbon isotope excursion in North America. GFF 128(2), 85-90.

DOI 10.1080/11035890601282085

Cramer, B.D., Loydell, D.K., Samtleben, C., Munnecke, A., Kaljo, D., Männik, P., Martma, T., Jeppsson, L., KlefFner, M.A., Barrick, J.E., Johnson, C.A., Emsbo, P., JoAchimski, M.M., Bickert, T. \& SAltzMAn, M.R. 2010. Testing the limits of Paleozoic chronostratigraphic correlation via high-resolution $(<500,000$ yrs) integrated conodont, graptolite, and carbon isotope $\left(\delta^{13} \mathrm{C}_{\text {carb }}\right)$ biochemostratigraphy across the Llandovery-Wenlock boundary: Is a unified Phanerozoic timescale achievable? Geological Society of America Bulletin 122, 1700-1716. DOI 10.1130/B26602.1

DUFKA, P. 1995. Upper Wenlock miospores and cryptospores derived from a Silurian volcanic island in the Prague Basin (Barrandian area, Bohemia). Journal of Micropalaeontology 14, 67-79. DOI 10.1144/jm.14.1.67

Fiala, F. 1970. Silurian and Devonian diabases of the Barrandian Basin. Journal of Geological Sciences, Geology 17, 7-71.

FRÝDA, J. \& MANDA, Š. 2013. A long-lasting steady period of isotopically heavy carbon in the late Silurian ocean: evolution of the $\delta^{13} \mathrm{C}$ record and its significance for an integrated $\delta^{13} \mathrm{C}$, graptolite and conodont stratigraphy. Bulletin of Geosciences 88(2), 463-482. DOI 10.3140/bull.geosci.1436

Gocke, M., Lehnert, O. \& FrÝdA, J. 2013. Facies development across the Late Silurian Lau Event based on temperate carbonates of the Prague Basin (Czech Republic). Facies 59(3), 611-630. DOI 10.1007/s10347-012-0328-y

Gutiérrez-Marco, J.C., Lenz, A.C., Robardet, M. \& Piçarra, J.M. 1996. Wenlock-Ludlow graptolite biostratigraphy and extinction: a reassessment from the southwestern Iberian Peninsula (Spain and Portugal). Canadian Journal of Earth Sciences 33, 656-663. DOI 10.1139/e96-049

HaVlíčEK, V. 1995. New data on the distribution of brachiopods in the Motol and lowest Kopanina formations (Wenlock, lower Ludlow, Prague Basin, Bohemia). Věstník Českého geologického ústavu 70(4), 47-63.

Havlíček, V., Horný, R., Chlupáč, I. \& Šnajdr, M. 1958. Průvodce ke geologickým exkursím do Barrandienu. Sbirka geologických průvodcủ 1.157 pp. Nakladatelství ČSAV, Praha. 
HAVLíčEK, V. \& ŠToRCH, P. 1990. Silurian brachiopods and benthic communities in the Prague Basin (Czechoslovakia). Rozpravy Ústředního ústavu geologického 48, 1-275.

HAVlíčEK, V. \& ŠToRCH, P. 1999. Silurian and Lochkovian communities of the Prague Basin (Barrandian area, Czechoslovakia), 200-228. In Boucot, A.J. \& LAwson, J.D. (eds) Final report, project Ecostratigraphy. Paleocommunities: A case study from the Silurian and Lower Devonian. Cambridge University Press, Cambridge.

Hejna, M. 2012. Lomy a vápenice v srdci Českého krasu. 92 pp. Envidea o.s., Praha.

HladíKOvÁ, J., Hladil, J. \& KŘ́íBeK, B. 1997. Carbon and oxygen isotope record across Pridoli to Givetian stage boundaries in the Barrandian basin (Czech Republic). Palaeogeography, Palaeoclimatology, Palaeoecology 132, 225-241. DOI 10.1016/S0031-0182(97)00062-X

HoRnÝ, R. 1954. Předběžná zpráva o výzkumu facií stř̌edočeského západního siluru. Věstník Ústředního ústavu geologického 29, 32-38.

Horný, R. 1955a. Base vrstev kopaninských eß 1 na jihozápadním okraji vulkanické facie (Kosov u Berouna). Věstník Ústredního ústavu geologického 30, 81-86.

HoRnÝ, R. 1955b. Předběžná zpráva o výzkumu vrstev budňanských eß ve východním Barrandienu. Věstník Ústředního ústavu geologického 30, 127-136.

HoRNÝ, R. 1955c. Studie o vrstvách budňanských v západní části Barrandienu. Sborník Ústredního ústavu geologického, Oddíl geologický 21, 315-447.

HoRnÝ, R. 1960. Stratigraphy and tectonics of the western closures of the Silurian-Devonian synclinorium in the Barrandian area. Sborník Ústředního ústavu geologického, Oddělení geologické 1, 495-524.

Horný, R. 1962. Das mittel böhmische Silur. Geologie 11(8), 873-916.

Horný, R. 1965. Tectonic structure and development of the Silurian between Beroun and Tachlovice. Časopis pro mineralogii a geologii 10(2), 147-156.

HoRnÝ, R. 1971. Problémy na hranici stupňů wenlock a budňan (silur, Iiteňské a kopaninské souvrství). Časopis Národního muzea, Oddíl př́rodovědný 140 (1/2), 25-35.

JAEGER, H. 1959. Graptolithen und Stratigraphie des jüngsten Thüringer Silurs. Abhandlungen der Deutschen Akademie der Wissenschaften zu Berlin, Klasse für Chemie, Geologie und Biologie 2, 1-197.

JAEGER, H. 1991. New standard graptolite zonal sequence after the 'Big Crisis' at the Wenlockian/Ludlowian boundary (Silurian). Neues Jahrbuch für Geologie und Paläontologie, Abhandlungen 182, 303-354.

JEPPSSON, L. 1998. Silurian oceanic events: Summary of general characteristics, 239-257. In LANDing, E. \& Johnson, M.E. (eds) Silurian Cycles: Linkages of Dynamic Stratigraphy with Atmospheric, Oceanic and Tectonic Changes. New York State Museum Bulletin 491.

JePpsSOn, L., AldRIDGE, R.J. \& Dorning, K.J. 1995. Wenlock (Silurian) oceanic episodes and events. Journal of the Geological Society of London 152, 487-498.

DOI 10.1144/gsjgs.152.3.0487.

JePpsson, L. \& CALNER, M. 2003. The Silurian Mulde Event and a scenario for secundo-secundo events. Transactions of the Royal Society of Edinburgh Earth Sciences 93, 135-154.

Jeppsson, L., ERiksson, M.E. \& CALner, M. 2006. A latest Llandovery to latest Ludlow high-resolution biostratigraphy based on the Silurian of Gotland - A summary. GFF 128, 109-114. DOI 10.1080/11035890601282109

Jeppsson, L., Talent, J.A., Mawson, R., Simpson, A.J., Andrew, A., CAlner, M., Whitford, D., Trotter, J.A., SAndström, O. \& CALDON, H.J. 2007. High-resolution Late Silurian correlations between Gotland, Sweden, and the Broken River region, NE Australia: lithologies, conodonts and isotopes. Palaeogeography, Palaeoclimatology, Palaeoecology 245, 115-137. DOI 10.1016/j.palaeo.2006.02.032

Johnson, M.E. 2006. Relationship of Silurian sea-level fluctuations to oceanic episodes and events. GFF 128, 115-121. DOI 10.1080/11035890601282115

Kaljo, D., Boucot, A.J., Corfield, R.M., Koren', T.N., Kř́ǐz, J., Le Hérrisé, A., Männik, P., Märs, T., Nestor, V., Shaver, R.H., Siveter, D.J. \& ViIRA, V. 1996. Silurian bio-events, 173-224. In Walliser, O.H. (ed.) Global Events and Events Stratigraphy in the Phanerozoic. Springer-Verlag, Berlin.

Kaljo, D., Grytsenko, V., Martma, T. \& Mõtus, M.-A. 2007. Three global carbon isotope shifts in the Silurian of Podolia (Ukraine): Stratigraphical implications. Estonian Journal of Earth Sciences 56, 205-220. DOI 10.3176/earth.2007.02.

Kaljo, D., KiIPli, T. \& Martma, T. 1997. Carbon isotope event markers through the Wenlock-Pridoli sequence at Ohesaare (Estonia) and Priekule (Latvia). Palaeogeography, Palaeoclimatology, Palaeoecology 132, 211-223. DOI 10.1016/S0031-0182(97)00065-5

Kaljo, D. \& Martma, T. 2006. Application of carbon isotope stratigraphy to dating the Baltic Silurian rocks. GFF 128(2), 123-129. DOI 10.1080/11035890601282123

Kaljo, D., Martma, T., Männik, P. \& Vitra, V. 2003. Implications of Gondwana glaciations in the Baltic late Ordovician and Silurian and a carbon isotopic test of environmental cyclicity. Bulletin de la Société géologique de France 174, 59-66. DOI 10.2113/174.1.59

Kodym, O., BouČEK, B. \& Šulc, J. 1931. Guide to the geological excursion to the neighbourhood of Beroun, Koněprusy and Budňany. Knihovna Státního geologického ústavu Československé republiky 15, 1-83.

KoREN', T.N. 1991. The lundgreni extinction event in central Asia and its bearing on graptolite biochronology within the Homerian. Proceedings of the Estonian Academy of Sciences, Geology 40, 74-78.

Kর̌ı̇̌̆, J. 1975. Revision of the Lower Silurian stratigraphy in Central Bohemia. Věstník Ústředního ústavu geologického 50, 275-282.

KŘiž, J. 1984. Silur, 20-31. In KovandA, J. (ed.) Vysvětlivky k základní geologické mapě ČSSR, 1:25 000, Rudná. Ústřední ústav geologický, Praha.

KŘiž, J. 1991. The Silurian of the Prague Basin (Bohemia) - tectonic, eustatic and volcanic controls on facies and faunal development. Special Papers in Palaeontology 44, 179-203.

KŘiž, J. 1992. Silurian field excursions: Prague Basin (Barrandian), Bohemia. National Museum Wales, Geological Series 13, 1-111.

KŘiž, J., 1998. Silurian, 79-101. In ChLUPÁč, I., HavlíčEK, V., KŘiž, J., Kukal, Z. \& ŠTorch, P. Paleozoic of the Barrandian (Cambrian to Devonian). Český geologický ústav, Praha.

KŘiž, J., DufKa, P., Jaeger, H. \& Schönlaub, H.P. 1993. The Wenlock/Ludlow Boundary in the Prague Basin (Bohemia). Jahrbuch der Geologischen Bundesanstalt A 136(4), 809-839.

KozŁowska-Dawidziuk, A., Lenz, A. \& ŠTorch, P. 2001. Upper Wenlock and Lower Ludlow (Silurian), post-extinction graptolites, V̌̌eradice section, Barrandian Area, Czech Republic. 
Journal of Palaeontology 75, 147-164. DOI 10.1666/0022-3360(2001)075<0147:UWALLS>2.0.CO;2

Lehnert, O., FrÝdA, J., Buggisch, W. \& Manda, Š. 2003. A first report of the Ludlovian Lau event from the Prague Basin (Barrandian, Czech Republic). Serie Correlación Geológica $18,139-144$.

Lehnert, O., Frýda, J., Buggisch, W., Munnecke, A., Nützel, A., Kř́̇̌̌, J. \& MANDA, Š. 2007. $\delta^{13}$ C record across the Ludlow Lau Event: new data from mid palaeo-latitudes of northern peri-Gondwana (Prague Basin, Czech Republic). Palaeogeography, Palaeoclimatology, Palaeoecology 245, 227-244. DOI 10.1016/j.palaeo.2006.02.022

LENZ, A.C. 1993. Late Wenlock-Ludlow (Silurian) extinction, evolution, and biostratigraphy: Perspectives from Arctic Canada: Canadian Journal of Earth Sciences 30, 491-498. DOI 10.1139/e93-038.

LenZ, A.C. \& KozŁowskA-Dawidziuk, A. 2001. Upper Wenlock (Silurian) graptolites from Arctic Canada: Pre-extinction, lundgreni biozone fauna. Palaeontographica Canadiana 20, 1-61.

Lenz, A.C. \& KozŁowska-DawidzIUK, A. 2002. Late Wenlock and early Ludlow graptolite extinction, evolution and diversification: A reassessment. Special Papers in Palaeontology 67 , 171-183.

Lenz, A.C. \& Melchin, M.J. 1989. Monograptus spiralis and its phylogenetic relationship to early cyrtograptids. Journal of Paleontology 63, 341-348.

Lenz, A.C., Noble, P.J., Masiak, M., Poulson, S.R. \& KozŁowSKA-DAwIDZIUK, A. 2006. The lundgreni Extinction Event: integration of paleontological and geochemical data from Arctic Canada. GFF 128(2), 153-158. DOI 10.1080/11035890601282153

LoYDELL, D.K. 1998. Early Silurian sea-level changes. Geological Magazine 135, 447-471. DOI 10.1017/S0016756898008917

Loydell, D.K. 2007. Early Silurian positive $\delta^{13} \mathrm{C}$ excursions and their relationship to glaciations, sea-level changes and extinction events. Geological Journal 42(5), 531-546. DOI 10.1002/gj.1090

LOYDELL, D.K. 2012. Graptolite biozone correlation charts. Geological Magazine 149, 124-132. DOI 10.1017/S0016756811000513

LOYDELL, D.K. \& FRÝDA, J. 2007. Carbon isotope stratigraphy of the upper Telychian and lower Sheinwoodian (Llandovery-Wenlock, Silurian) of the Banwy River section, Wales. Geological Magazine 144, 1015-1019. DOI 10.1017/S0016756807003895

LOYDELL, D.K. \& FRÝDA, J. 2011. At what stratigraphical level is the mid Ludfordian (Ludlow, Silurian) positive carbon isotope excursion in the type Ludlow area, Shropshire, England? Bulletin of Geosciences 86(2), 197-208. DOI 10.3140/bull.geosci. 1257

Loydell, D.K., MÄnNiK, P. \& Nestor, V. 2003. Integrated biostratigraphy of the lower Silurian of the Aizpute-41 core, Latvia. Geological Magazine 140, 205-229. DOI 10.1017/S0016756802007264

Loydell, D.K., Nestor, V. \& MÄnNiK, P. 2010. Integrated biostratigraphy of the lower Silurian of the Kolka-54 core, Latvia. Geological Magazine 147, 253-280. DOI 10.1017/S0016756809990574

Manda, Š. 1996. Cyrtograptus lundgreni Zone in the southwestern part of the Svatý Jan Volcanic Centre (Wenlock, Prague Basin). Věstník Českého geologického ústavu 71(4), 369-374.

MandA, Š. 2007. New Silurian nautiloids Phragmoceras Broderip, 1839, and Tubiferoceras Hedström, 1917, from the
Prague Basin (Bohemia). Bulletin of Geosciences 82(2), 119-131. DOI 10.3140/bull.geosci.2007.02.119

MANDA, Š. \& FRÝDA, J. 2010. Silurian-Devonian boundary events and their influence on cephalopod evolution: evolutionary significance of cephalopod egg size during mass extinctions. Bulletin of Geosciences 85(3), 513-540. DOI 10.3140/bull.geosci.1174

Manda, Š., ŠTorch, P., Slavík, L., FrÝda, J., KŘíž, J. \& TASÁRYOVÁ, Z. 2012. Graptolite, conodont and sedimentary record through the late Ludlow Kozlowskii Event (Silurian) in shale dominated succession of Bohemia. Geological Magazine 149(3), 507-531. DOI 10.1017/S0016756811000847

Marshall, C., Thomas, A.T., Boomer, I. \& Ray, D.C. 2012. High resolution $\delta^{13} \mathrm{C}$ stratigraphy of the Homerian (Wenlock) of the English Midlands and Wenlock Edge. Bulletin of Geosciences 87(4), 669-679. DOI 10.3140/bull.geosci.1306

Murphy, M.A., Valenzuela-Ríos, J.I. \& Carls, P. 2004. On classification of Pridoli (Silurian) - Lochkovian (Devonian) Spathognathodontidae (Conodonts). University of California, Riverside, Campus Museum Contribution 6, 1-25.

Munnecke, A., Samtleben, C. \& Bickert, T. 2003. The Ireviken Event in the lower Silurian of Gotland, Sweden - relation to similar Palaeozoic and Proterozoic events. Palaeogeography, Palaeoclimatology, Palaeoecology 195, 99-124. DOI 10.1016/S0031-0182(03)00304-3

Noble, P.J., Lenz, A.C., Holmden, C., Masiak, M., Zimmerman, M.K., Poulson, S.R. \& KozŁowska, A. 2012. Isotope geochemistry and plankton response to the Ireviken (Earliest Wenlock) and Cyrtograptus lundgreni Extinction Events, Cape Phillips Formation, Arctic Canada, 631-652. In TALENT, J.A. (ed.) Earth and Life - Global Biodiversity, Extinction Intervals and Biogeographic Perturbations Through Time. Series: International Year of Planet Earth. 1100 pp. Springer. DOI 10.1007/978-90-481-3428-1_12.

Noble, P.J., Zimmerman, M.K., Holmden, C. \& Lenz, A.C. 2005. Early Silurian (Wenlockian) $\delta^{13} \mathrm{C}$ profiles from the Cape Phillips Formation, Arctic Canada and their relation to biotic events. Canadian Journal of Earth Sciences 42, 1419-1430. DOI 10.1139/e05-055

PERNER, J. 1903-1911. Recherches paléontologiques. Volume 4, Gastéropodes. In BARRANDE, J. Système silurien du centre de la Bohême. Prague.

Perner, J. \& Kodym, O. 1919. O rozčlenění svrchního siluru v Čechách. Časopis Musea Království českého 93, 6-24.

Pittau, P., Cotza, F., Cristini, S., Del Rio, M. \& Loi, M. 2006. Palaeontologic and biogeochemical characterization of the C. lundgreni Event in the black shales of eastern mid-Sardinia. Lethaia 39, 111-127. DOI 10.1080/00241160600578885

Porębska, E., KozŁowska-Dawidziuk, A. \& Masiak, M. 2004. The lundgreni event in the Silurian of the East European platform, Poland. Palaeogeography, Palaeoclimatology, Palaeoecology 213, 271-294. DOI 10.1016/j.palaeo.2004.07.013

Ray, D.C., Thomas, A.T. \& Marshall, C. 2011a. The Much Wenlock Limestone Formation: The Nature Conservancy Council Cutting, Wren's Nest Hill, Dudley, 121-129. In RAY, D.C. (ed.) Siluria Revisited: A Field Guide: International Subcommission on Silurian Stratigraphy, Field Meeting, 2011, Ludlow, England. International Subcommission on Silurian Stratigraphy.

Ray, D.C., Thomas, A.T. \& Marshall, C. 2011b. Latest Homerian obrution deposits: Upper Quarried Limestone Member, Quarry Trench, Mons Hill, Dudley, 130-135. In RAY, D.C. (ed.) Siluria Revisited: A Field Guide: International Subcommission on Silurian Stratigraphy, Field Meet- 
ing, 2011, Ludlow, England. International Subcommission on Silurian Stratigraphy.

SADLER, P.M. 2012. Integrating carbon isotope excursions into automated stratigraphic correlation: an example from the Silurian of Baltica. Bulletin of Geosciences 87(4), 681-694. DOI 10.3140/bull.geosci.1307

Saltzman, M.R. 2001. Silurian $\delta^{13} \mathrm{C}$ stratigraphy: a view from North America. Geology 29, 671-674.

DOI 10.1130/0091-7613(2001)029<0671:SCSAVF $>2.0 . C O ; 2$

Samtleben, C., Munnecke, A., Bickert, T. \& Patzold, J. 1996. The Silurian of Gotland (Sweden): facies interpretation based on stable isotopes in brachiopod shells. Geologische Rundschau 85, 278-292. DOI 10.1007/BF02422234

Steemans, P., Petus, E., Breuer, P., Mauller-Mendlowicz, P. \& Gerrienne, P. 2012. Palaeozoic innovations in the micro and megafossil plant record: from the earliest plant spores to the earliest seeds, 437-477. In TALENT, A.J. (ed.) Earth and Life - Global Biodiversity, Extinction Intervals and Biogeographic Perturbations Through Time, International Year of Planet Earth. 1100 pp. Springer. DOI 10.1007/978-90-481-3428-1_13.

Svoboda, J. \& Prantl, F. 1953. O stratigrafii a tektonice staršího paleozoika mezi Srbskem a Sv. Janem pod Skalou. Sborník Ústředního ústavu geologického 22, 205-276.

Štorch, P. 1987. Silur, 31-41. In Chlupáč, I. (ed.) Vysvětlivky kzákladní geologické mapě ČSSR, 1:25 000, Beroun. Ústřední ústav geologický, Praha.

S̆тоRсн, P. 1994. Graptolite biostratigraphy of the Lower Silurian (Llandovery and Wenlock) of Bohemia. Geological Journal 29, 137-165. DOI 10.1002/gj.3350290204

ŠтоRсн, P. 1995. Biotic crises and post-crisis recoveries recorded by graptolite faunas of the Barrandian area, Czech Republic. Geolines 3, 59-70.

Štorch, P. 1998. Volcanism, 149-164. In Chlupáč, I., HavLíčEK, V., KŘiž, J., KuKal, Z. \& Štorch, P. Palaeozoic of the Barrandian (Cambrian to Devonian). Český geologický ústav, Praha.

S̆TORCH, P. \& FRÝDA, J. 2009. Carbon isotope data and graptolite record in the lower Silurian (Llandovery) of northern periGondwana - exemplified by Barrandian area, Czech Republic, 347-348. In Corriga, M.G. \& Piras, S. (eds) Time and Life in the Silurian: A multidisciplinary approach. Sub- commission on Silurian Stratigraphy Field Meeting 2009, Abstracts. Supplemento al Bolletino della Società Paleontologica Italiana 48(1), Rendiconti della Società Paleontologica Italiana 3.

ŠTORCH, P. \& FRÝDA, J. 2012. Late Aeronian graptolite sedgwickii Event, associated carbon isotope excursion and facies changes in the Prague Synform (Barrandian, Bohemia). Geological Magazine 149(6), 1089-1106.

DOI 10.1017/S001675681200026X

Stricanne, L., Munnecke, A. \& Pross, J. 2006. Assessing mechanisms of environmental change: palynological signals across the late Ludlow (Silurian) positive isotope excursion $\left(\delta^{13} \mathrm{C}, \delta^{18} \mathrm{O}\right)$ on Gotland, Sweden. Palaeogeography, Palaeoclimatology, Palaeoecology 230, 1-31. DOI 10.1016/j.palaeo.2005.07.003

SutTNER, T.J. 2007. Conodont stratigraphy, facies-related distribution patterns and stable isotopes (carbon and oxygen) of the uppermost Silurian to lower Devonian Seewarte section (Carnic Alps, Carinthia, Austria). Abhandlungen der Geologischen Bundesanstalt 59, 1-111.

Torsvik, T.H. 2009. BugPlates: Linking Biogeography and Palaeogeography. Available from:

http://www.geodynamics.no/bugs/SoftwareManual.pdf (accessed 4 December 2012).

TuREK, V. 1990. Comments to upper Wenlock zonal subdivisions in the Silurian of Central Bohemia. Poznámky k zonálnímu členění svrchního wenlocku ve středočeském siluru. Časopis pro mineralogii a geologii 35(4), 337-353.

Wenzel, B. \& Joachimski, M.M. 1996. Carbon and oxygen isotopic composition of Silurian brachiopods (Gotland/Sweden): palaeoceanographic implications. Palaeogeography, Palaeoclimatology, Palaeoecology 122(1), 143-166. DOI 10.1016/0031-0182(95)00094-1

Williams, M. \& Zalasiewicz, J. 2004. The Wenlock Cyrtograptus species of the Builth Wells District, central Wales. Palaeontology 47(2), 223-263. DOI 10.1111/j.0031-0239.2004.00372.x

ŽelízKo, J.V. 1904. Notiz über die Korallen des mittelböhmischen Obersilur aus dem Fundorte "V Kozle". Verhandlungen der Kaiserlich-königlichen geologischen Reichsanstalt 13, 304-307.

\section{Appendix}

On-going systematic study of Homerian (late Wenlock) carbonate sequences in the Central Segment of the Prague Basin (sensu Kříž 1992) reveals a chaos in usage of their informal lithostratigraphic names. To prevent future misunderstandings we establish here a new formal lithostratigraphic name (Kozel Limestone Member) for the limestone sequence studied in present paper.

\section{Kozel Limestone Member (new member)}

(vápence Kozla in Czech lithostratigraphic nomenclature)

Etymology. - According to geographic name "Kozel" or " $V$ Kozle", which has been used for natural rock outcrops formed by newly established stratigraphic unit at its type area.

Previous informal names. - Limestone unit involved here into a new lithostratigraphic unit (Kozel Limestone Member) has been intensively studied by geologists and paleontologists since the first half of the nineteenth century, but no formal lithostratigraphic name was hitherto established for it. However several informal names were used for it during last two centuries: "Rochers de Kozel" or "Kozel" (Barrande 1852-1881, Perner 1903-1911), "V Kozle" (Želízko 1904), "útesováfacie" (Perner \& Kodym 1919), "korálové vápence" (Kodym et al. 1931), "kalkige Fazies" (Bouček 1934), "kopaninské vápence" (Svoboda \& Prantl 1953), "lištické facie" (Horný 1954), "lištické vápence" (Horný 1954, but not Horný 1955, and Kříž 1987), “organodetritické dolomitické vápence komplexu 'Kozla", (Horný 1955a), "organodetritické tufitické dolomitické vápence, facie 'Kozla”' (Horný 1965), 
“vápence facie 'Kozla"'(Horný 1965, Štorch 1987), "karbonátový komplex 'Kozla”' (Horný 1971), “'Kozel' Limestone Complex” (Kư̌iž et al. 1993, Kříz 1998).

Definition. - Mostly crinoidal, and locally tuffaceous and dolomitic limestone unit occurring in the Central Segment of the Prague Basin and forming the upper part of the Motol Formation above the C. lundgreni graptolite Biozone. Newly established Kozel Limestone Member belongs to the Motol Formation sensu Kříž (1975).

Stratotype and parastratotype. - Section No. 760 described in detail by Křiž et al. (1993) on the left (north) bank of the Berounka River, about $1 \mathrm{~km}$ south of the village of Lištice near Beroun is selected here as stratotype of the Kozel Limestone Member. The latter section is one of two complete and uncovered sections (i.e., section No. 760 and "Kozel Syncline" section situated about $1.5 \mathrm{~km}$ E of section No. 760, and $600 \mathrm{~m} \mathrm{~W}$ of estuary of the Kačák brook) across whole thickness of the Kozel Limestone Member. Lithology of some levels of "Kozel Syncline" section differs from the stratotype section (see below) and for this reason the "Kozel Syncline" section is established here as a parastratotype of the Kozel Limestone Member. The both sections (stratotype and parastratotype) are situated on the left (north) bank of the Berounka River and this area is the type area for the Kozel Limestone Member.

Lithology. - Lithologic properties of the Kozel Limestone Member were strongly influenced by its shallow water origin as well as volcanic activity of neighbouring Svatý Jan Volcano. Crinoidal-coral-brachiopod-bryozoan grainstones, rudstones and packstones containing variable amount of tuffitic and/or dolomitic component represent the most frequent lithotypes of the Kozel Limestone Member. Alternation of these lithotypes latterally as well as vertically is rather quick, often at distances of few meters. The Kozel Limestone Member involves locally also several tuffitic and dolomitic layers which are developed laterally for several hundreds meters, but not across the whole geographic distribution of the Kozel Limestone Member. There is a distinct increasing trend in amount of tuffitic material occuring in limestone sequence from southeast (parastratotype) to northwest (stratotype) but opposite trend in occurrence of dolomite as was already noted by Horný (1955c).

Geographic distribution. - The Kozel Limestone Member is restricted to the Central Segment of the Prague Basin and reaches maximal thickness about $60 \mathrm{~m}$ at its south limit close to the Tobolka Fault (Horný 1965, Křřž 1992). Northwards its thickness decreases and its occurrences could be traced for several kilometers along the Tachlovice Fault up to the village of Vysoký Újezd (about $5 \mathrm{~km} \mathrm{SW}$ of Prague).
Total tickness of the Kozel Limestone Member about $3 \mathrm{~km}$ $\mathrm{N}$ of its type area (sections at village of Svatý Jan pod Skalou) reached several tens meters (Štorch 1987 and 2014 pers. comm.). Details on individual occurrences of the Kozel Limestone Member (but under different informal names mentioned above) could be found in Svoboda \& Prantl (1953), Horný (1954, 1955a-c, 1960, 1965, 1971), Křřž (1984, 1998), Křiž et al. (1993), and Štorch (1987).

Fauna. - The high diverse fauna of the Kozel Limestone Member consists mostly of crinoids, corals, stromatoporoids, brachiopods, bryozoans, gastropods and trilobites (for details see Barrande 1852-1881; Želízko 1904; Perner 1903-1911; Kodym et al. 1931; Bouček 1934; Havlíček et al. 1958; Horný 1955a-c, 1962, 1965, 1971; Havlíček \& Štorch 1990, 1999; Kř́iž 1991, 1992, 1998; Kříž et al. 1993; Havlíček 1995, and references herein).

Age. - Middle and upper part of the Homerian and probably the lowermost Gorstian (see discussion above).

Relation to lithostratigraphic units. - The Kozel Limestone Member could be easily distinguished from adjacent rocks of the Motol Formation. In its type area the Kozel Limestone Member is underlain by an interval, more than $20 \mathrm{~m}$ thick, formed by volcaniclastic rocks. The youngest strata of the Kozel Limestone Member are overlain by volcaniclastic and volcanic rocks having a total thickness of several hundreds meters. Laterally the Kozel Limestone Member is passing into calcareous and tuffitic shales (see detailed discussion in Svoboda \& Prantl 1953; Horný 1955a-c, 1965, 1971; Kříž 1984, 1992, 1998; Křiž et al. 1993; Štorch 1987).

Relation to biostratigraphic units. - As mentioned above precise biostratigraphic dating of the Kozel Limestone Member is difficult because of a lack of biostratigraphically significant fossils (see above). Available data suggests that its age is younger than the $C$. lundgreni graptolite Biozone. Upper limit of the Kozel Limestone Member is difficult to infer from biostratigraphic data, again because of a lack of stratigraphically significant fossil. However its age inferred from chemostratigraphic data suggests that the Kozel Limestone Member corresponds to an interval from the $P$. parvus-G. nassa Biozone to the lowermost Gorstian (see discusion above).

Relation to chemostratigraphic units. - The Kozel Limestone Member corresponds roughly to the two-peaked Homerian $\delta^{13} \mathrm{C}$ excursion and involves all four chemostratigraphic zones of the Homerian carbon isotope excursion (i.e., R1-, F1-, R2- and F2-zones established above) and a short interval above the F2-Zone (see discussion in present paper). 